\title{
Cytotoxicity induced by carbon nanotubes in experimental malignant glioma
}

\author{
This article was published in the following Dove Press journal: \\ International Journal of Nanomedicine \\ 21 August 2017 \\ Number of times this article has been viewed
}

\author{
Samuel Romano-Feinholz ${ }^{1, *}$ \\ Alelí Salazar-Ramiro ${ }^{2, *}$ \\ Emilio Muñoz-Sandoval ${ }^{3}$ \\ Roxana Magaña-Maldonado ${ }^{2}$ \\ Norma Hernández Pedro ${ }^{4}$ \\ Edgar Rangel López ${ }^{5}$ \\ Alberto González Aguilar ${ }^{1}$ \\ Aurora Sánchez García ${ }^{6}$ \\ Julio Sotelo \\ Verónica Pérez de la $\mathrm{Cruz}^{7}$ \\ Benjamín Pineda ${ }^{2}$ \\ 'Division of Neurosurgery, \\ ${ }^{2}$ Neuroimmunology and Neuro- \\ oncology Unit, National Institute \\ of Neurology and Neurosurgery \\ (NINN), Mexico City, ${ }^{3}$ Division of \\ Advanced Materials, IPICYT, San \\ Luis Potosí, ${ }^{4}$ Experimental Oncology \\ Laboratory, National Cancer \\ Institute of Mexico, ${ }^{5}$ Excitatory \\ Aminoacids Laboratory, ${ }^{6}$ Pathology \\ Laboratory, ${ }^{7}$ Neurochemistry Unit, \\ National Institute of Neurology \\ and Neurosurgery (NINN), Mexico \\ City, Mexico \\ *These authors contributed equally \\ to this work
}

Correspondence: Benjamín Pineda Neuroimmunology and Neuro-oncology Unit, National Institute of Neurology and Neurosurgery (NINN), Insurgentes sur 3877, I 4269 Mexico City, Mexico

Tel +52 5556064040

Email benpio76@hotmail.com

Verónica Pérez de la Cruz

Neurochemistry Unit, National Institute of Neurology and Neurosurgery (NINN), México City, Mexico

Tel +52 5556063822 (ext 2006)

Email veped@yahoo.com.mx
Abstract: Despite multiple advances in the diagnosis of brain tumors, there is no effective treatment for glioblastoma. Multiwalled carbon nanotubes (MWCNTs), which were previously used as a diagnostic and drug delivery tool, have now been explored as a possible therapy against neoplasms. However, although the toxicity profile of nanotubes is dependent on the physicochemical characteristics of specific particles, there are no studies exploring how the effectivity of the carbon nanotubes (CNTs) is affected by different methods of production. In this study, we characterize the structure and biocompatibility of four different types of MWCNTs in rat astrocytes and in RG2 glioma cells as well as the induction of cell lysis and possible additive effect of the combination of MWCNTs with temozolomide. We used undoped MWCNTs (labeled simply as MWCNTs) and nitrogen-doped MWCNTs (labeled as N-MWCNTs). The average diameter of both pristine MWCNTs and pristine N-MWCNTs was $\sim 22$ and $\sim 35 \mathrm{~nm}$, respectively. In vitro and in vivo results suggested that these CNTs can be used as adjuvant therapy along with the standard treatment to increase the survival of rats implanted with malignant glioma.

Keywords: carbon nanotubes, glioblastoma therapy, temozolomide, malignant glioma

\section{Background}

The incidence of primary tumors of the central nervous system (CNS) is 30,000 cases per year in the USA. Glioblastoma (GBM) is the most frequent primary malignant tumor in adults and constitutes about $30 \%$ of all tumors of the CNS. ${ }^{1}$ Every year, GBM accounts for $2.3 \%$ of all cancer-related deaths. Despite several clinical trials during the last decades, the improvement in therapy has been faint. ${ }^{2}$ Currently, the best treatment available consists of surgery followed by radiotherapy and chemotherapy with temozolomide (TMZ) ${ }^{3}$ however, even with this multimodal approach, the overall survival is about $12-15$ months with a tumor recurrence rate of $60 \%-90 \%$ after surgery and radiotherapy; less than $5 \%$ of patients have a survival longer than 5 years. $^{4}$

Due to the lack of response to treatment, new therapeutic options are being developed. Recently, the use of nanoparticles as a possible therapeutic option has been studied due to their biocompatibility and low toxicity. Carbon nanotubes (CNTs) are graphene sheets rolled in a cylindrical manner with a high aspect ratio relation which represent an important group of nanomaterials with geometric, mechanical, electrical and chemical properties that are ideal for diverse applications. ${ }^{5}$ There are two structural types of CNTs: single-walled CNTs (SWCNTs), constituted by a single graphite sheet rolled in a cylindrical tube, and multiwalled carbon nanotubes (MWCNTs), constituted by two or more graphite layers folded around an axis $;{ }^{6}$ CNTs have been used as drug carriers of various chemotherapeutic agents to induce selective toxicity in tumor cells. Also, CNTs can be functionalized to increase their bioavailability, and because of their submit your manuscript Dovepress $5 y$ in 6

http://dx.doi.org/10.2147/IN.S139004 
size, they can flow freely through the bloodstream and inside organs such as the spleen, liver and kidneys. ${ }^{8}$

However, functionalization methods need to be carefully applied to carbon nanomaterials to achieve biocompatibility with the cells. Depending on application, there are two types of functionalization of CNTs, namely covalent and non-covalent. Hong et al reviewed the subject and produced an extended discussion about these two types of functionalization. ${ }^{9}$ Sayes et al showed that the functionalization of the SWCNTs influences the toxicity response of cells in culture, and found that the SWCNT sample had larger cytotoxic effect if its surface was functionalized. ${ }^{10}$ Coccini et al studied the cytotoxicity of both pristine MWCNTs and MWCNTs functionalized with carboxyl and amine groups in human astrocytoma D384 and lung carcinoma A549 cells using MTT assay and calcein/propidium iodide (PI) staining; they showed that CNTs increased cytotoxicity. ${ }^{11}$ To overcome the multidrug resistance of some forms of cancer, Yao et al proposed the use of distearoylphosphatidylethanolamine-hyaluronic acid conjugate to functionalize and increase the biocompatibility of SWCNTs, in this case, combined with epirubicin. ${ }^{12}$ Using thermal and microwave methods, Tahermansouri and Ghobadinejad functionalized carboxylated short MWCNTs (sh-MWCNTs) with creatinine and aromatic aldehydes for treatment of human breast and gastric cancer cells; they found that the functionalized Sh-MWCNTs had less toxicity on the breast cancer cells than on the gastric cancer cells. ${ }^{13}$ To combat cancer multidrug resistance and radioresistance in hepatocellular carcinoma, non-covalent-functionalized MWCNTs have been used as carriers of anticancer ruthenium polypyridyl complexes. ${ }^{14}$ One of the most resistant neoplasms to treatment is the peritoneal metastases of colorectal cancer; chemotherapy has not been effective in eliminating these malignant cells. Graham et al proposed the use of folic acid-functionalized MWCNTs to target colorectal cancer cells and reduce them by photothermal therapy. ${ }^{15}$ As MWCNTs can transform near-infrared laser radiation into heat, they have been used as immunoconjugates for cancer phototherapy. ${ }^{16}$ Functionalized MWCNTs have also been intravenously administrated, after they were transformed in a drug delivery system with diethylenetriaminepentaacetic dianhydride molecules attached to their surface. This molecule has also served as a substrate to anchor the gamma-emitting radionuclide, and this nanosystem was followed by a microSPECT/computer tomography; the authors proposed that the elimination mechanism of MWCNTs observed was due to the rapid desorption of the radionuclide attached to the MWCNTs in the blood. ${ }^{17}$
Marega et al used functionalized Fe-filled MWCNTs as multifunctional scaffolds for magnetization of cancer cells; they anchored monoclonal antibodies (mAbs) against cancer cells on the surface of Fe-filled MWCNTs to evaluate the confinement of magnetically active Fe phases and the immobilization of mAbs on MWCNTs surface. ${ }^{18}$ de Faria et al investigated the efficiency of a hybrid supramolecule as an anticancer vaccine; it included MWCNTs as a delivery system for NY-ESO-1, which is a cancer antigen, and a Tolllike receptor agonist; this strategy restrained the tumoral growth. ${ }^{19}$ Previous studies have proved that functionalized CNTs (CNTFn) may be more easily internalized into cells; moreover, CNTFn are able to cross the plasmatic membrane and reach the perinuclear region after $2 \mathrm{~h}$ of incubation, ${ }^{20}$ which makes them a relevant possible therapeutic agent for GBM treatment. The above-mentioned studies are few examples of the immense amount of investigations that are carried out on the use of MWCNTs as a potential biomedical system for cancer therapies. The objective of this work was to determine the cytotoxic effect of CNTs in normal astrocytes and in cultured RG2 cells as well as to explore the mechanism by which CNTs induce this effect.

\section{Materials and methods Chemicals}

Dulbecco's Modified Eagle's Medium (DMEM) was purchased from Fisher Scientific (Waltham, MA, USA). Penicillin, streptomycin, PI, RNase, MTT and TMZ were purchased from Sigma-Aldrich. TMZ was dissolved in dimethylsulfoxide (DMSO; Sigma Chemicals Co., Perth, Mexico) for assays. Acridine orange was obtained from Polysciences (Warrington, PA, USA).

\section{Nanotubes fabrication}

Nitrogen-doped multiwalled carbon nanotubes (N-MWCNTs) were fabricated by pyrolyzing a solution of ferrocene $\left(\mathrm{Fe}\left(\mathrm{C}_{5} \mathrm{H}_{5}\right)_{2}\right)$ and benzylamine $\left(\mathrm{C}_{6} \mathrm{H}_{5} \mathrm{CH}_{2} \mathrm{NH}_{2}\right)$ by the method of aerosol-assisted chemical vapor deposition (AACVD). The solution was obtained as $2.5 \%$ of ferrocene by weight in benzylamine. First, the solution was mixed using an ultrasonic cleaner (Bronson 2510 with output $100 \mathrm{~W}, 42 \mathrm{~Hz}$ ) for $30 \mathrm{~min}$. Benzylamine was used to include nitrogen atoms to the graphitic network of MWCNTs, and it is also a source of carbon atoms. Ferrocene was used to generate iron or ironcarbon nanoparticles which are the catalyst for CNTs production. Ferrocene also contributed with the carbon atoms of N-MWCNTs. The CVD system consisted of two tube furnaces placed together, and within them was a quartz tube, where the 
reaction was carried out. The mixed solution was placed inside a vessel (Pyrex) with a piezoelectric sensor on its base. The synthesis started when the furnaces were at $850^{\circ} \mathrm{C}$. Then, a cloud of the mixed solution was formed and transported to the quartz tube by a mixture of argon and hydrogen $(95 \%-5 \%)$. The flow of this mixture was set to be $2.5 \mathrm{~L} / \mathrm{min}$ during the synthesis process. The fabrication of N-MWCNTs was carried out for $30 \mathrm{~min}$, and then the furnaces were turned off, the operation of frequency generator was terminated and the gas flow was kept till the temperature of the system reached $200^{\circ} \mathrm{C}$. To quench the fabricated materials, the furnaces were cooled by two fans. The pristine material produced within quartz tube was carefully scraped from the furnaces surface and collected in weighing paper, and then it was weighed and stored in aluminum foil or in glass vials for characterization. Undoped MWCNTs were fabricated using the same equipment and same operating conditions but with a different mixed solution. Instead of benzylamine, toluene was used as the source of carbon. The same proportions were employed in the mixed solution, namely $2.5 \%$ of ferrocene by weight in toluene. The temperature and the time of synthesis were changed; the temperature was $825^{\circ} \mathrm{C}$ for $15 \mathrm{~min}$. The sample was collected by scraping, similar to the N-MWCNTs.

\section{Nanotubes functionalization}

The chemical functionalization of N-MWCNTs was performed using a $4 \mathrm{M}$ aqueous mixture of sulfuric acid and nitric acid $(3: 1, \mathrm{v} / \mathrm{v})$, giving a total of $400 \mathrm{~mL}$ homogeneous mixture. The ratio of N-MWCNTs and the acid mixture was $1: 1$ (same volume [mL] of acid for same amount [mg] of N-MWCNTs). This substance was sonicated for $30 \mathrm{~min}$ in an Erlenmeyer flask. Then, extensive washing with distilled water was carried out until the $\mathrm{pH}$ value of the flushed solution was $\sim 7$. The material obtained after this procedure was named N-MWCNTs-ox. The same process was applied for the functionalization of undoped MWCNTs, but the time of sonication was $2 \mathrm{~h}$ and $30 \mathrm{~min}$. The resultant material was called MWCNTs-ox.

\section{Characterization}

The fabricated or pristine samples were characterized by using an FEI Helios 600 Nanolab apparatus operating at $5 \mathrm{kV}$, and a high-resolution transmission electron microscope operating at $300 \mathrm{kV}$ (FEI Tecnai F30 STWIN G2). To have homogeneous material for characterization, $20 \mathrm{mg}$ of the sample was dissolved in $100 \mathrm{~mL}$ ethanol and sonicated in an ultrasonic cleaner. Then, the solution was filtrated using the known vacuum filtration technique employing nylon membrane filters (Whatman) with $0.2 \mu \mathrm{m}$ pore size and $25 \mathrm{~mm}$ diameter. The resultant material was dried at $66^{\circ} \mathrm{C}$ for $24 \mathrm{~h}$. A self-supporting MWCNT membrane was separated from the nylon membrane and used for scanning electron microscopy. A small part of this membrane was again dispersed in ethanol in an ultrasonic cleaner for $5 \mathrm{~min}$. Several small drops of this suspension were placed on a holey-carbon grid and dried at $66^{\circ} \mathrm{C}$ for $24 \mathrm{~h}$ for characterization by highresolution transmission electron microscopy (HRTEM).

\section{Cell cultures}

Cell culture studies were performed using RG2 cell line, which is commonly used as a rat brain tumor model. It grows well in cell culture and provides a simple reproducible glioma model when it is inoculated in Fisher syngenic rats, and it is one of the more similar cell groups to human glioma. Also, primary astrocytes in cell culture were used as nonmalignant control cells as the origin of GBM tumors is from transformed astrocytes. Astrocytes were isolated from 3 -day-old Fisher rats, as previously described. ${ }^{21}$ Animal care and use of all experimental animals were performed in accordance with institutional ethical guidelines. RG2 GBM tumor cell lines (RG2 cells) were acquired from the American Type Culture Collection (ATCC, Manassas, VA, USA). The cells were cultured with DMEM (Thermo Fisher Scientific) and supplemented with $10 \%$ bovine fetal serum (Thermo Fisher Scientific), $4 \mathrm{mM}$ glutamine and $100 \mathrm{U} / \mathrm{mL}$ of penicillin-streptomycin. They were cultured under sterile conditions at $37^{\circ} \mathrm{C}$ in a humid atmosphere with $5 \% \mathrm{CO}_{2}$.

\section{Cytotoxicity determination}

The cytotoxicity was determined for all CNTs in rat astrocytes and RG2 cells. Briefly, cells were cultured in 24-well plates $\left(1 \times 10^{5}\right.$ cells $)$ and treated with different concentrations of MWCNTs $(10,20,30,40,50,60,70,80,90$ and $100 \mu \mathrm{g} / \mathrm{mL}$ ). After $24 \mathrm{~h}$, cells were collected. Cell suspensions were incubated with PI in $100 \mu \mathrm{L}$ of binding buffer. After gently vortexing, cells were incubated for $15 \mathrm{~min}$ at room temperature in darkness. Then, $400 \mu \mathrm{L}$ of binding buffer was added, and cells were analyzed by flow cytometry within $1 \mathrm{~h}$ after treatment evaluating 10,000 events. Data were collected on a FACSCalibur instrument (BD Biosciences). Cell QuestPro and FlowJo ver. 7.6.1 software were used for data analysis.

\section{Cell viability analysis}

As the effect on cellular cytotoxicity was not dependent on CNTs concentration, we used a concentration of $50 \mu \mathrm{g} / \mathrm{mL}$ 
for each MWCNT, and cell viability was evaluated in the following groups: Group 1: pristine N-MWCNT; Group 2: N-MWCNT-ox; Group 3: pristine MWCNT; Group 4: MWCNT-ox; Group 5: TMZ $(10 \mu \mathrm{M})$ and Groups 6-9: TMZ with the four different MWCNTs. (Where appropriate, we use "MWCNTs" to refer to any of these nanotubes in a generic way.) Cell viability was determined by two experimental strategies: PI and MTT reduction assays. Briefly, after $24 \mathrm{~h}$ of incubation, cells were rinsed with PBS and resuspended in $1 \mathrm{~mL}$ of filtered PBS, and adjusted to a final concentration of $1 \times 10^{6}$ cells $/ \mathrm{mL}$. Then, cells were incubated with PI and evaluated as described $(1 \mu \mathrm{g} / \mathrm{mL})$.

\section{MTT reduction assay}

Cellular function was evaluated by the MTT reduction assay, as reported in previous reports. ${ }^{22,23}$ This method is currently employed either as a functional status index of the respiratory chain or as an index of overall functional status in the whole cell. The formation of formazan salts occurs through the action of dehydrogenases in viable cells. After treatment, the medium was removed, and the cells were washed with Hanks medium, and then $200 \mu \mathrm{L}$ of MTT $(5 \mathrm{mg} / \mathrm{mL}$ in PBS) was added to each well. The reaction was allowed to proceed for $4 \mathrm{~h}$ at $37^{\circ} \mathrm{C}$, and then the medium was removed and the blue formazan product was eluted with isopropanol. Quantification of formazan was done by optical density at a wavelength of $570 \mathrm{~nm}$ in a plate reader (EON; BioTek). Results were expressed as the percentage of MTT reduction in relation to control values.

\section{Determination of cell death mechanisms Apoptosis detection with Annexin $\mathrm{V}$ assay and PI double stain}

After the experimental treatments, the cells were rinsed and resuspended in $1 \mathrm{~mL}$ of filtered PBS and adjusted to a final concentration of $1 \times 10^{6}$ cells $/ \mathrm{mL}$. Cell suspensions were incubated with APC-labeled Annexin V (Annexin V Apoptosis Detection Kit I; BD Pharmingen) and 7AAD in $100 \mu \mathrm{L}$ of binding buffer. After gentle vortexing, cells were incubated for $15 \mathrm{~min}$ at room temperature in darkness, and $400 \mu \mathrm{L}$ of binding buffer was added to analyze the cells by flow cytometry within $1 \mathrm{~h}$ after treatment. A total of 10,000 events were evaluated. Data were collected on a FACSCalibur instrument (BD Biosciences). Cell QuestPro and FlowJo ver. 7.6.1 software were used for data analysis. The dot plot of the four quadrants in the figures was used to distinguish the viable (Annexin V-/7AAD-), early apoptotic (Annexin V+/7AAD-), late apoptotic (Annexin V+/7AAD+) and necrotic (Annexin $\mathrm{V}-/ 7 \mathrm{AAD}+$ ) cells. ${ }^{24}$

\section{Mitochondrial membrane potential $(\Delta \psi \mathrm{m})$}

$\Delta \psi \mathrm{m}$ in glioma cells was assessed by flow cytometry (Becton-Dickinson, Franklin Lakes, NJ, USA) using the JC-1 aggregate-forming lipophilic cation (Thermo Fisher Scientific) as previously described. ${ }^{25}$ When mitochondria has low membrane potential, JC-1 is in its monomeric form and displays green fluorescence (FL-1 channel, emission length at $525 \mathrm{~nm}$ ), whereas in the mitochondrial matrix, with high membrane potential, JC-1 forms red fluorescence aggregates (FL-2 channel, emission length at $590 \mathrm{~nm}$ ). Briefly, after $24 \mathrm{~h}$ of treatment, cells were collected by adding $70 \mu \mathrm{L} /$ well of trypsin $(0.025 \%)$, centrifuged at 2,000 rpm for $5 \mathrm{~min}$ and decanted. RG2 glioma cells were labeled with JC-1 at a final concentration of $3 \mu \mathrm{M}$ at $37^{\circ} \mathrm{C}$ for $30 \mathrm{~min}$. Treated cells were gated in the corresponding cell region. Data were expressed as mean fluorescence intensity in FL-2 channel $(\Delta \psi \mathrm{m}){ }^{25}$

\section{Autophagy assays}

\section{Autophagy analysis by LC3}

The microtubule-associated protein 1 light-chain 3 (LC3) is essential for amino-acid starvation-induced autophagy, and it is associated with the autophagosome membrane. ${ }^{26-28} \mathrm{RG} 2$ cells $\left(1 \times 10^{6}\right)$ were cultured on six-well plates. After treatment, the cells were fixed in $4 \%$ paraformaldehyde, blocked with 3\% normal goat serum and incubated in $1 \% \mathrm{BSA} / 10 \%$ normal goat serum/0.3 M glycine in $0.1 \%$ PBS-Tween for $1 \mathrm{~h}$ to permeabilize the cells and to block nonspecific proteinprotein interactions. Afterwards, cells were incubated with the goat polyclonal anti-LC3A/B (Abcam, Cambridge, UK) for $30 \mathrm{~min}$. Then, cells were washed twice with PBS and incubated for additional $30 \mathrm{~min}$ in darkness with an anti-goat IgG antibody coupled with APC (Abcam), washed again with PBS and finally acquired using a FACSCalibur flow cytometer using the CellQuest software and FlowJo 10x for the final analysis (Becton-Dickinson).

\section{Acridine orange vesicles (AVOs)}

Autophagy is characterized by the formation and promotion of acidic vesicular organelles (AVOs). ${ }^{29}$ We used the lysosomotropic agent acridine orange that moves freely across biological membranes when it is uncharged; its protonated form accumulates in acidic cell compartments, where it forms aggregates that fluoresce bright red. ${ }^{30,31}$ Flow cytometry with acridine orange staining was employed to detect and quantify the AVOs. In acridine orange-stained cells, the cytoplasm and nucleus fluoresce bright green and dim red, respectively, whereas acidic compartments fluoresce bright red. ${ }^{29}$ Therefore, we measured the change in the intensity of the red fluorescence to obtain the percentage of cellular 
acidic compartments. After the treatments with MWCNTs, $\mathrm{TMZ}$ alone or TMZ combined with MWCNTs, $1 \times 10^{5}$ cells were collected in phenol red-free RPMI 1640 medium. The green (FL-1) and red (FL-3) fluorescence of acridine orange was measured with a flow cytometer using the CellQuest software (Becton-Dickinson). The sum of the upper-left and the upper-right quadrants of the dot plot was used to represent the percentage of autophagy. These assays were done in triplicate.

\section{Reactive oxygen species determination}

Reactive oxygen species (ROS) production was detected by fluorescence of dichlorofluorescein (DCF). ${ }^{32,33}$ RG2 cells were preincubated with $75 \mu \mathrm{M}$ DCFH-DA for $10 \mathrm{~min}$ to allow DCFH-DA to diffuse into cells. Immediately thereafter, RG2 cells were incubated in the absence (control) or presence of the different CNTs alone or combined with $\mathrm{TMZ}$ at $37^{\circ} \mathrm{C}$ for $1 \mathrm{~h}$ when ROS levels were detected at the intracellular domain, and at variable times (30 and $60 \mathrm{~min}$ and 3 and $6 \mathrm{~h}$ ) when the ROS levels were detected at both intracellular and extracellular domains. Intracellular ROS formation was assessed by flow cytometry, considering 10,000 total events for determination of the medium fluorescence index in the FlowJo program. Extracellular ROS was conventionally detected in supernatants by fluorescence spectrometry using a Perkin-Elmer LS50 spectrometer at $488 \mathrm{~nm}$ (excitation wavelength) and $532 \mathrm{~nm}$ (emission wavelength). Then, final DCF concentrations were calculated by interpolation of curve of a DCF standard incubated in parallel. Results were expressed as percent of ROS formation vs control.

\section{Cell cycle analysis}

The cells were seeded at $3 \times 10^{5}$ per well in six-well plates. After incubation for $24 \mathrm{~h}$, cells were treated with each group of MWCNTs, TMZ alone or TMZ combined with the four groups of MWCNTs. After 24-h incubation, cells were harvested, fixed in $70 \%$ ethanol and stored at $-20^{\circ} \mathrm{C}$. Cells were then washed twice with pre-cold PBS and incubated with RNase and PI for 30 min at dark, and cell cycle phase analysis was performed using the FlowJo analysis software (Becton Dickinson Immunocytometry Systems, San Jose, CA, USA).

\section{In vivo treatment}

Before intracranial implantation, RG2 cells were briefly treated with trypsin to detach them from culture bottle, centrifuged and resuspended in the corresponding medium. The cell suspensions were regularly shaken to prevent cell sedimentation and kept in a sterile vial at $4^{\circ} \mathrm{C}$ until stereotactic implantation.

\section{Orthotopic glioma model}

For the rat RG2 glioma cell implantation model, Fischer 344 male rats (BioInvert, Mexico City, Mexico), 3 months old $(n=50)$, were fed ad libitum. The cell implantation procedure was conducted as described by Kobayashi et al. ${ }^{34}$ Briefly, each animal was anesthetized (ketamine 40-90 mg/kg intraperitoneally administered plus xylazine $5-10 \mathrm{mg} / \mathrm{kg}$ subcutaneously administered) and immobilized on a stereotaxic unit (Stoelting Co., Wood Dale, IL, USA). After disinfection and incision of the head skin with a scalpel, a hole was drilled on the right-hand side of the skull $2 \mathrm{~mm}$ lateral and $2 \mathrm{~mm}$ anterior to the bregma. RG2 cells $\left(1 \times 10^{6}\right)$ suspended in $10 \mu \mathrm{L}$ of saline solution were injected at $3 \mathrm{~mm}$ in depth from the dura at a rate of $2 \mu \mathrm{L} / \mathrm{min}$, using a 25 -gauge Hamilton needle mounted on a $25 \mu \mathrm{L}$ Hamilton glass syringe (Hamilton, Reno, NV, USA). Two min after injection, the needle was retired.

Seven days after the implant, animals were separated into five groups ( $\mathrm{n}=10$ for each group), according to the treatment: the first group (control) was untreated, the second group was intratumorally injected with pristine N-MWCNTs ( $25 \mu \mathrm{g}$ in $25 \mu \mathrm{L}$ ), the third group was injected intratumorally with N-MWCNTs-ox $(25 \mu \mathrm{g}$ in $25 \mu \mathrm{L})$, the fourth group was injected intratumorally with pristine MWCNTs $(25 \mu \mathrm{g}$ in $25 \mu \mathrm{L})$ and the fifth group was injected intratumorally with MWCNTs-ox $(25 \mu \mathrm{g}$ in $25 \mu \mathrm{L})$. Animals were fed with food and water ad libitum until signs of tumor affection appeared or until the rats died as a consequence of brain tumor. We recorded the time of survival and performed a KaplanMeier survival analysis using the software SPSS ver. 10.

All animal experiments were approved by the Bioethics Committee and the Institutional Review Board (Number 78/13) of the National Institute of Neurology and Neurosurgery (NINN) and followed the regulations of the Mexican Standard for the production, care and use of laboratory animals (NOM-062-ZOO-1999).

\section{Drug toxicity on hematic and biochemical parameters}

For studies of blood count and blood chemistry screen (glucose, BUN, creatinine and liver function tests), five rats from each group were anesthetized, and blood samples were obtained by intracardiac puncture. The same parameters were measured in five healthy rats whose values were taken as control. 


\section{Statistical analysis}

Data were expressed as mean \pm SD. Statistical significance was evaluated by analysis of variance and the Tukey's range test using the SPSS software (ver. 11.5). $P<0.05$ was considered statistically significant. Cumulative survival was determined from day of implantation until death. Data were analyzed by the Kaplan-Meier test.

\section{Results}

\section{AACVD method allowed the production of symmetric MWCNTs}

Figure 1 shows the scanning electron microscope images of N-MWCNTs (A and B) and MWCNTs (C and D). N-MWCNTs and MWCNTs produced by the AACVD method had spaghetti-like shape and were aligned. N-MWCNTs (Figure 1A and B) showed metallic compounds over their surface; probably, the acid treatment reduced the amount and size of nanoparticles. In the case of MWCNTs (undoped), the result was different (Figure 1C); at the observed magnification, only very small detectable metallic nanoparticles (white points) were observed, and after acid treatment, such nanoparticles disappeared (Figure 1D). Figure $\mathrm{S} 1$ shows the transmission electron microscopy (TEM) images of N-MWCNTs before (A and $\mathrm{B})$ and $\operatorname{after}(\mathrm{C}$ and $\mathrm{D})$ the acid treatment. In Figure S1A
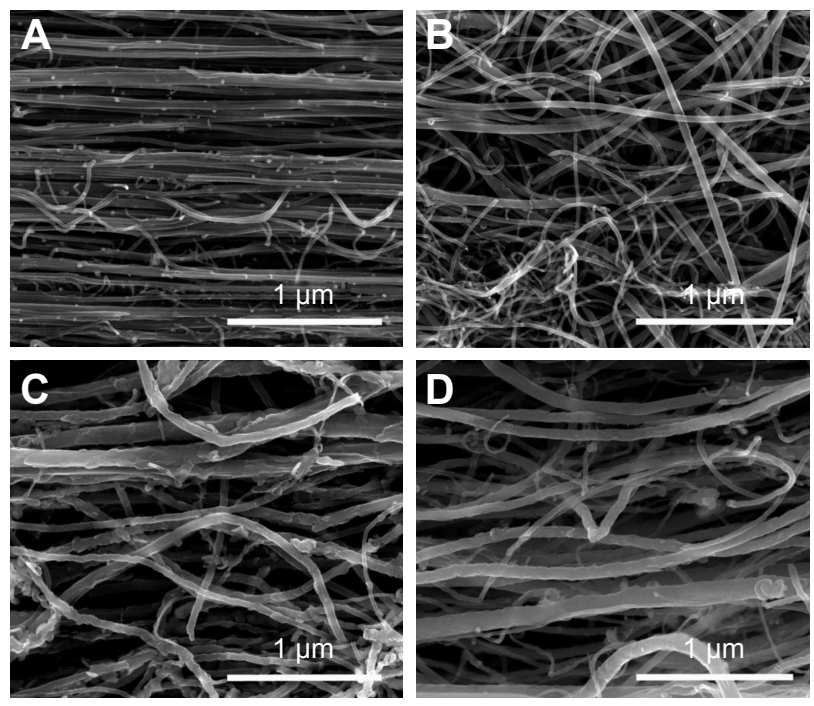

Figure I SEM images of N-MWCNTs ( $\mathbf{A}$ and $\mathbf{B}$ ) and MWCNTs (C and $\mathbf{D}$ ): pristine (A and $\mathbf{C})$ and after acid treatment (B and $\mathbf{D})$.

Notes: The N-MWCNTs well aligned with large amounts of iron carbide nanoparticles adhered on their surface (A). After acid treatment, the N-MWCNTs present almost no metallic nanoparticles attached to their outer carbon layer (B and D). The case of MWCNTs is different; few iron carbide nanoparticles are present adhered to their external surface ( $\mathbf{A}$ and $\mathbf{C})$. The acid treatment of MWCNTs induced serious disruption in their morphology (B and $\mathbf{D})$.

Abbreviations: N-MWCNTs, nitrogen-doped MWCNTs; MWCNTs, multiwalled carbon nanotubes. and $\mathrm{B}$, one can see several metallic nanoparticles attached to the CNT surface. After the acid treatment, the CNT surface had no metallic nanoparticles. A small protuberance can be observed in the superior part of CNTs in Figure S1D (black arrow); probably, it was a metallic nanoparticle coated before the acid treatment. Figure S2 shows the TEM images of MWCNTs before (A and B) and after acid treatment $(C$ and $D)$. One can find it hard to see attached nanoparticles before acid treatment (Figure S2A). However, encapsulated metallic nanoparticles are present on pristine MWCNTs (black arrow, Figure S2B). After acid treatment, the internal particles were also observed (black arrows, Figure S2C and D). Acid treatment also eliminated most of the nanoparticles from the surface of N-MWCNTs; however, internal nanoparticles inside undoped MWCNTs did not seem to be affected (Figure S2C and D). Figure S3 shows the HRTEM characterization of N-MWCNTs (A and B) and MWCNTs (C and D). It is evident that acid treatment affects the surface morphology of both N-MWCNTs and undoped MWCNTs. Figure S4 shows the dispersion of diameters before and after the acid treatment. In addition to the functionalization of nanotubes, the acid treatment might break the large nanotubes.

\section{Effect of MWCNTs on the viability of astrocytes and RG2 glioma cells}

Cell viability was assessed using PI in astrocytes (Figure 2) and in RG2 glioma cells (Figure 3 ) treated with different concentrations of the four different MWCNTs $(0-100 \mu \mathrm{g} / \mathrm{mL})$. As shown in Figures 2 and 3, the addition of MWCNTs to the culture medium increased the percentage of cell death from the lowest concentration used $(10 \mu \mathrm{g} / \mathrm{mL})$; however, this effect was not dependent on concentration. Although in all treated groups the cell viability was affected, MWCNT-ox group showed greater inhibition compared with controls (cells cultured without MWCNTs) which showed decrease in cell viability to $~ 50 \%$ after $24 \mathrm{~h}$ of incubation in both normal astrocytes and glioma RG2 cells (Figures 2 and 3). The results indicated that the four MWCNTs induced higher cell death in astrocytes than in RG2 glioma cells, indicating that MWCNTs are more cytotoxic in normal astrocytes than in malignant RG2 glioma cells. The different MWCNTs induced cytotoxicity in astrocytes in the following order: pristine N-MWCNT $<$ N-MWCNT-ox $=$ pristine MWCNT $<$ MWCNT. In the case of RG2 glioma cells, the order was: pristine N-MWCNT = pristine MWCNT $<$ N-MWCNT-ox $<$ MWCNT-ox. Based on the results obtained for 24-h treatment, the dose of $50 \mu \mathrm{g} / \mathrm{mL}$ was selected for subsequent experiments. 


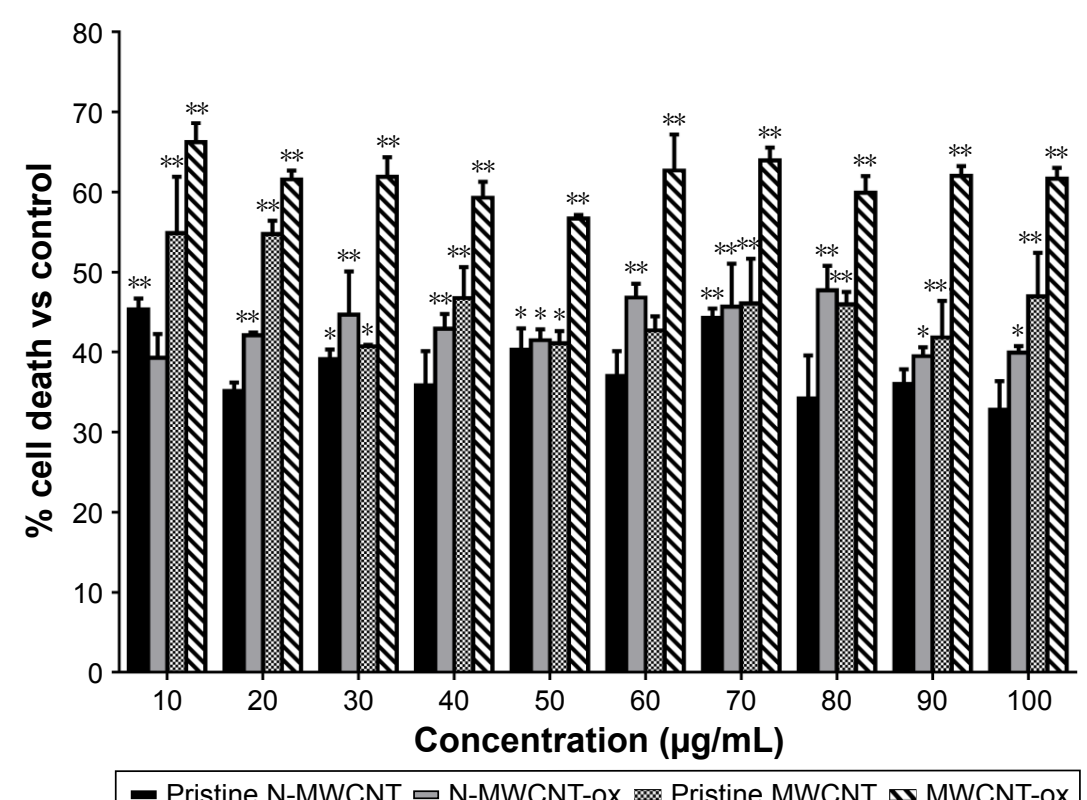

Figure 2 MWCNTs induce cell death in primary cultures of rat astrocytes.

Notes: Astrocytes were treated with different concentrations of MWCNTs. Graph shows mean \pm SEM of dead cells in a primary culture of rat astrocytes treated with MWCNTs. Rat astrocytes $\left(I \times 10^{6}\right)$ were treated with MWCNTs for $24 \mathrm{~h}$, and the percentage of dead cells was determined by FACS using propidium iodide stain. $* P<0.0 \mathrm{I}$ vs control and $* * P<0.001$ vs control.

Abbreviations: MWCNT, multiwalled carbon nanotube; N-MWCNT, nitrogen-doped MWCNT; N-MWCNT-ox, acid-treated nitrogen-doped MWCNT; MWCNT-ox, acid-treated MWCNT.

\section{Co-incubation of MWCNTs plus TMZ reduced viability of RG2 glioma cells}

Pristine N-MWCNTs and N-MWCNTs-ox $(50 \mu \mathrm{g} / \mathrm{mL})$ in contact with RG2 glioma cells for $24 \mathrm{~h}$ induced a significant
$20 \%$ reduction in cell viability in comparison with nontreated cells or cells treated with DMSO; no significant reduction was seen in the pristine MWCNT group. The main reduction in cell viability was seen in cells treated with MWCNTs-ox



Pristine N-MWCNT $\rightleftharpoons$ N-MWCNT-ox m Pristine MWCNT w MWCNT-ox

Figure 3 MWCNTs induce cell death in cultures of rat RG2 glioma cells.

Notes: RG2 glioma cells were treated with different concentrations of MWCNTs. Graph shows mean \pm SEM of lysis of RG2 glioma cells induced by MWCNTs. Glioma cells $\left(I \times \mid 0^{6}\right)$ were treated with different concentrations of MWCNTs for $24 \mathrm{~h}$, and the percentage of dead cells was determined by FACS using propidium iodide stain. $* P<0.0 \mathrm{I}$ vs control and $* * P<0.001$ vs control.

Abbreviations: MWCNT, multiwalled carbon nanotube; N-MWCNT, nitrogen-doped MWCNT; N-MWCNT-ox, acid-treated nitrogen-doped MWCNT; MWCNT-ox, acid-treated MWCNT. 
(two times higher than in the other treated groups). Combination with $\mathrm{TMZ}$ induced a significant increase in the percentage of dead cells (twice compared with MWCNTs alone) (Figure 4).

\section{Functionalized MWCNTs were more bioavailable than nonfunctionalized MWCNTs}

Functionalized MWCNTs (N-MWCNTs-ox or MWCNTs-ox) were more phagocytosed than their nonfunctionalized counterparts (pristine N-MWCNTs or pristine MWCNTs). Although no imaging techniques were done to assess changes in cell size due to the uptake of MWCNTs, images showed what seems to be an increase in the uptake of functionalized MWCNTs (Figure 5A). This uptake induced changes in size and internal complexity (Figure 5A and B) in cells treated with functionalized MWCNTs; these changes might be due to early stages of apoptosis (Figure 5A and B). In contrast, nonfunctionalized MWCNTs did not induce appreciable changes in the internal complexity (Figure 5A). TMZ did
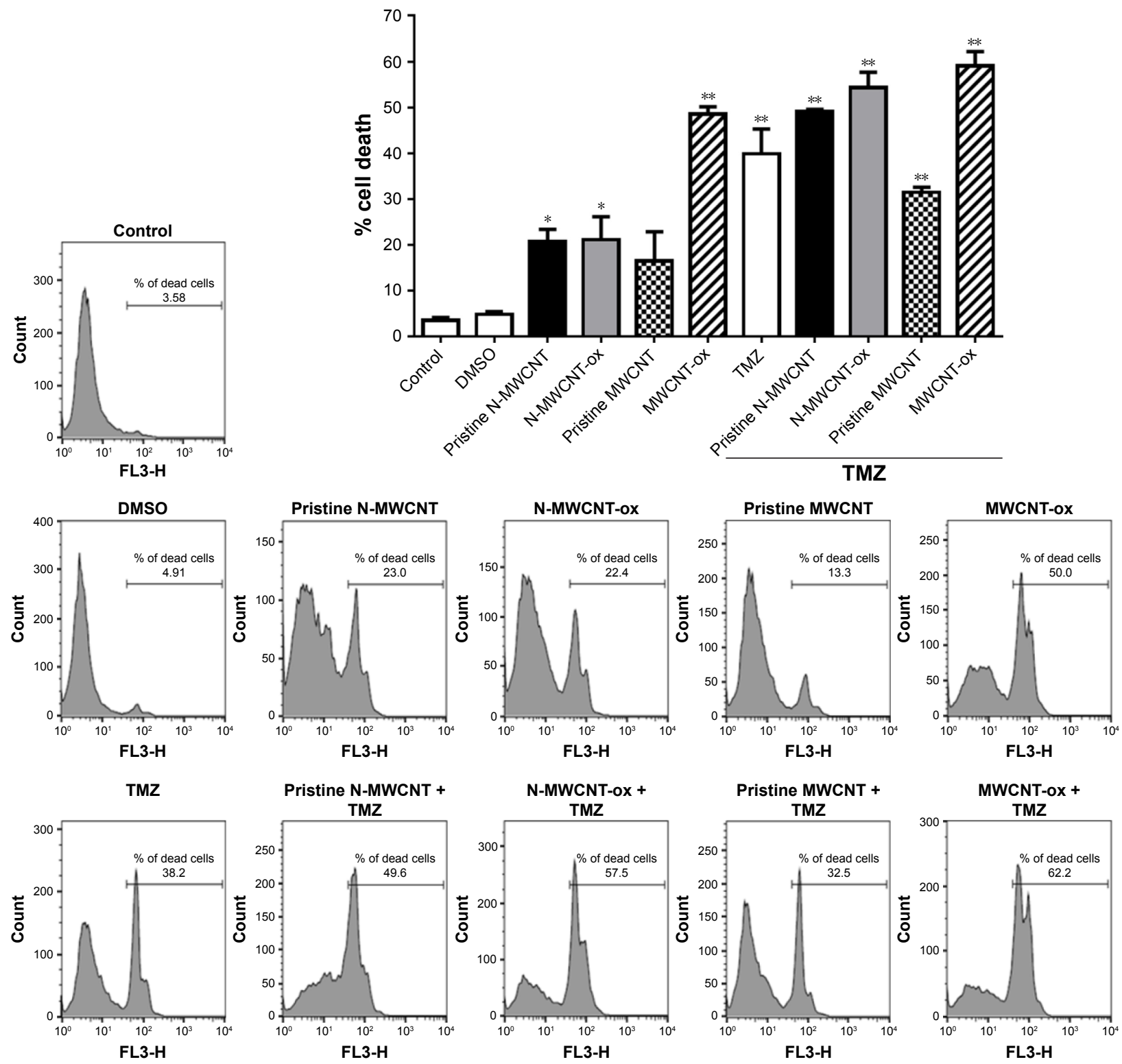

Figure 4 TMZ treatment increases MWCNTs cell death in RG2 glioma cells.

Notes: RG2 glioma cells were treated with $50 \mu \mathrm{g} / \mathrm{mL}$ of MWCNTs, TMZ or MWCNTs plus TMZ. Graph shows mean \pm SEM of dead RG2 glioma cells, and representative FACS histograms show the percentage of Pl+ cells. Glioma cells $\left(I \times 10^{6}\right)$ were treated with different concentrations of MWCNTs, TMZ or TMZ plus MWCNTs for $24 \mathrm{~h}$, and the percentage of dead cells was determined by FACS using propidium iodide stain. $* P<0.01$ vs control and $* * P<0.001$ vs control.

Abbreviations: TMZ, temozolomide; MWCNT, multiwalled carbon nanotube; N-MWCNT, nitrogen-doped MWCNT; N-MWCNT-ox, acid-treated nitrogen-doped MWCNT; MWCNT-ox, acid-treated MWCNT. 


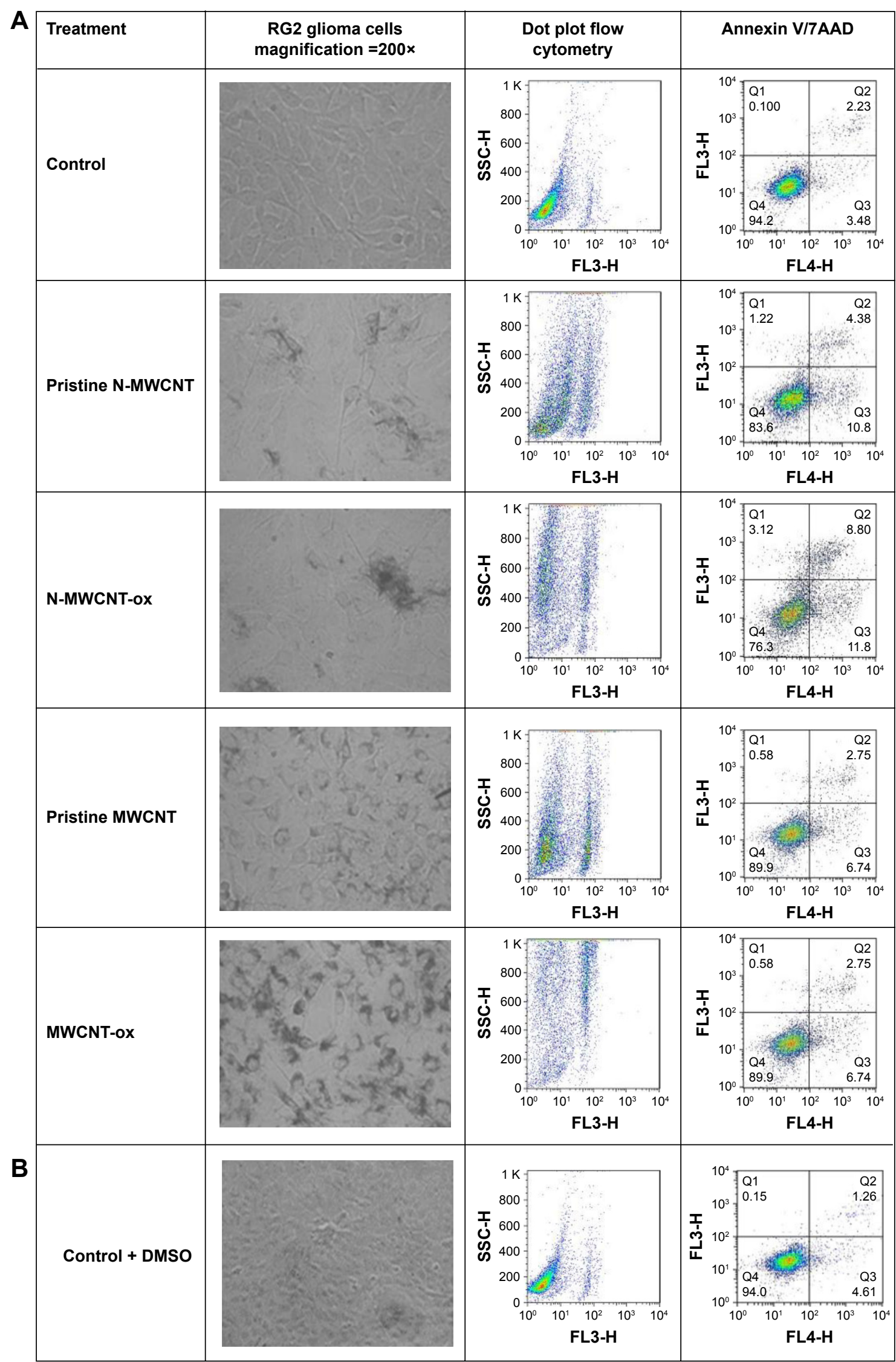

Figure 5 (Continued) 


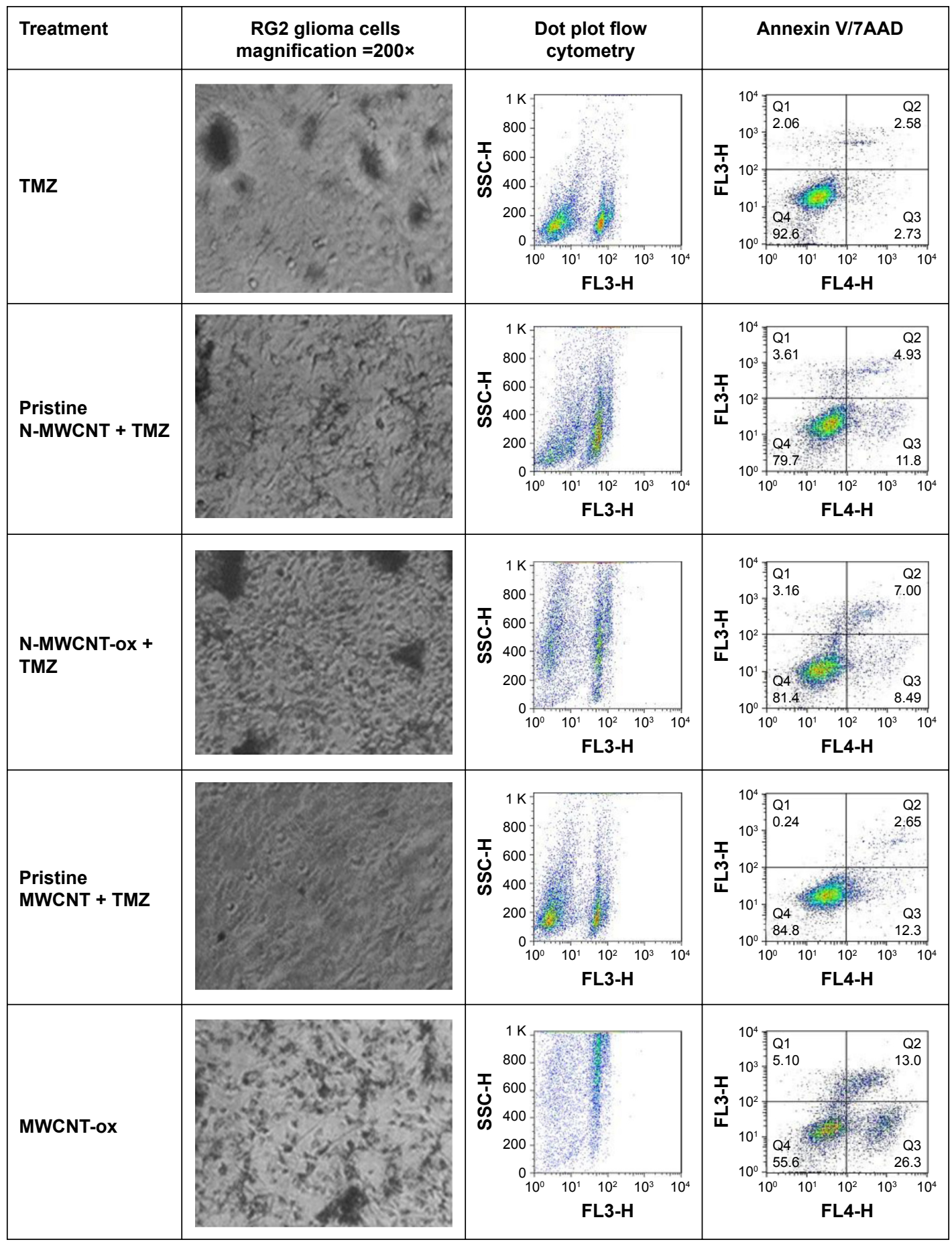

Figure 5 Effect of treatment with MWCNTs and TMZ in RG2 glioma cells.

Notes: MWCNTs are well phagocytosed by RG2 glioma cells (A). TMZ treatment does not affect the capacity of RG2 glioma cells to phagocytose MWCNTs (B). The representative images of RG2 glioma cells by light microscopy and FACS dot plots are shown. The microscopy images show that the cells endocytosed the four different MWCNTs used (A) and MWCNTs used in combination with TMZ, and the first row of dot plots shows the increase in size of the RG2 glioma cells due to the increase in the number of MWCNTs endocytosed. The second line of dot plots shows the representative images of the induction of apoptosis and necrosis by different MWCNTs endocytosed by RG2 cells.

Abbreviations: MWCNT, multiwalled carbon nanotube; TMZ, temozolomide; N-MWCNT, nitrogen-doped MWCNT; N-MWCNT-ox, acid-treated nitrogen-doped MWCNT; MWCNT-ox, acid-treated MWCNT.

not modify the intake of N-MWCNTs-ox or MWCNTs-ox by RG2 glioma cells (Figure 5B). Functionalization of CNTs allowed a better uptake distribution, preventing the formation of aggregates in astrocytes and in RG2 glioma cells.

\section{MWCNTs-ox induced apoptosis in RG2 rat glioma cells}

Figure $5 \mathrm{~A}$ and $\mathrm{B}$ shows the representative dot plots from cells treated with each of the four MWCNTs. The 
apoptosis-inducing effect of MWCNTs was investigated by flow cytometric analysis of RG2 cells stained with Annexin V-APC and PI. Exposure of cells to MWCNTs-ox $(50 \mu \mathrm{g} / \mathrm{mL})$ for $24 \mathrm{~h}$ induced more necrosis and apoptosis than exposure to the other three CNTs (Figures 6 and 7); however, this effect did not increase when MWCNTs-ox were combined with TMZ. These results suggest that some of the toxic effects induced by MWCNTs-ox are related to induction of apoptosis and necrosis.

A

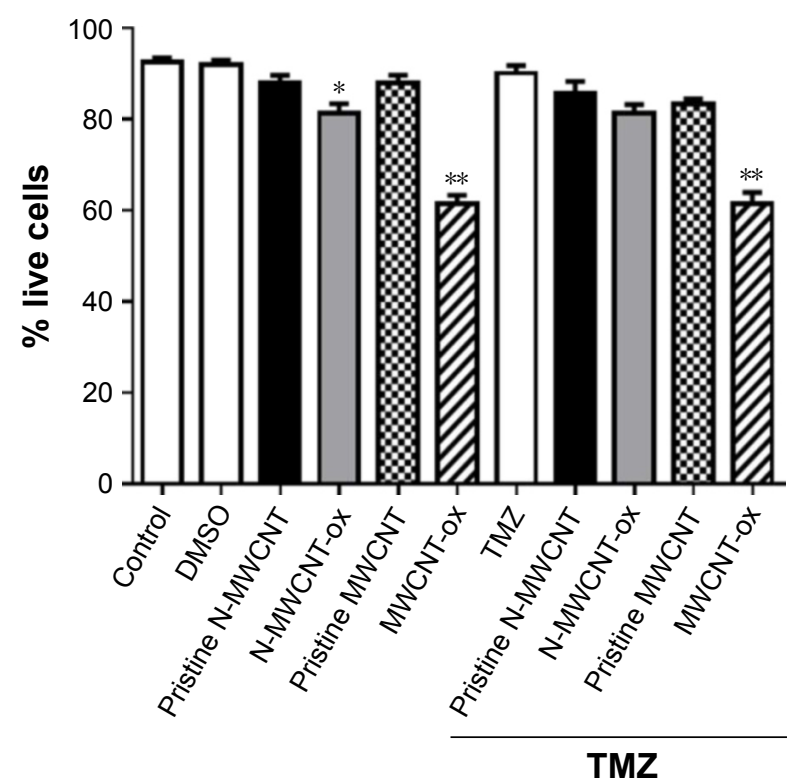

C

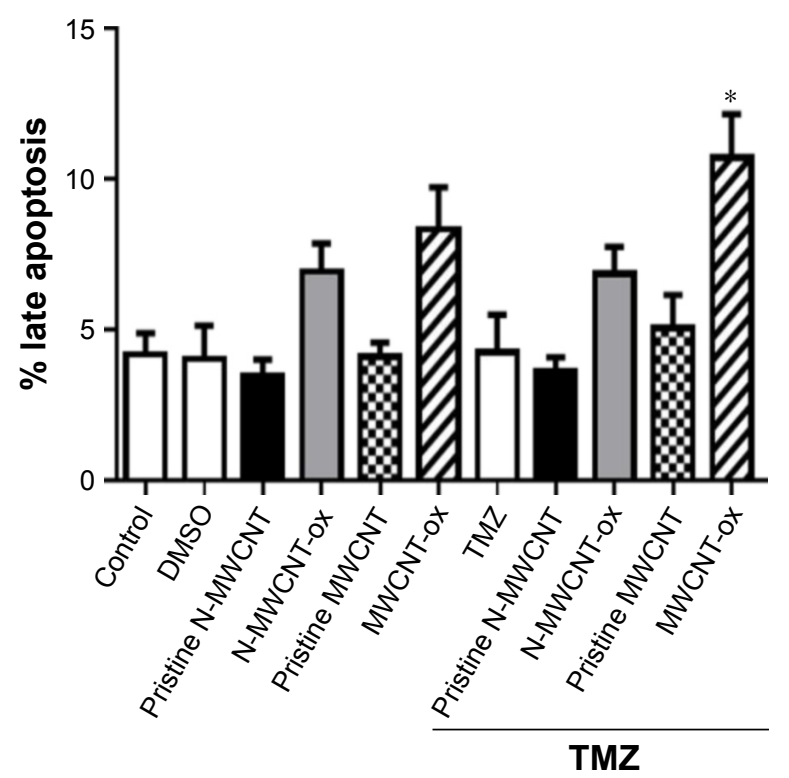

MWCNTs induced DNA fragmentation increasing sub-G0 peak in RG2 cells

The above-described results show that MWCNTs induce reduction of cell number and apoptosis. To clarify the underlying mechanism, flow cytometry was used to examine the effect of MWCNTs on the cell cycle (Figure 8). Results showed increase in the number of cells in the sub-G0 peak for RG2 cells treated with $50 \mu \mathrm{g} / \mathrm{mL}$ of any of the CNTs, and the effect increased when CNTs were combined

B

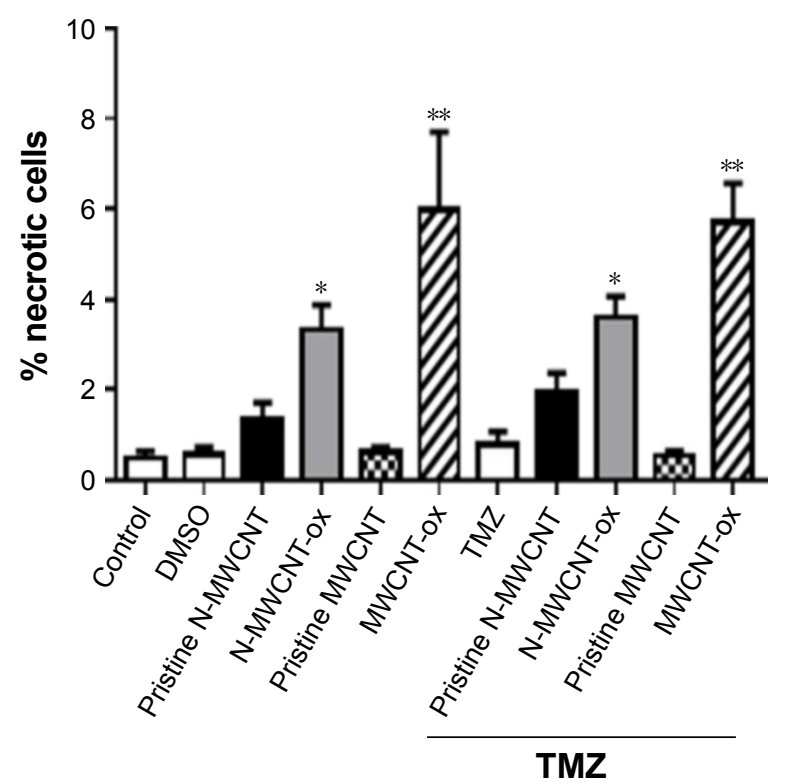

D

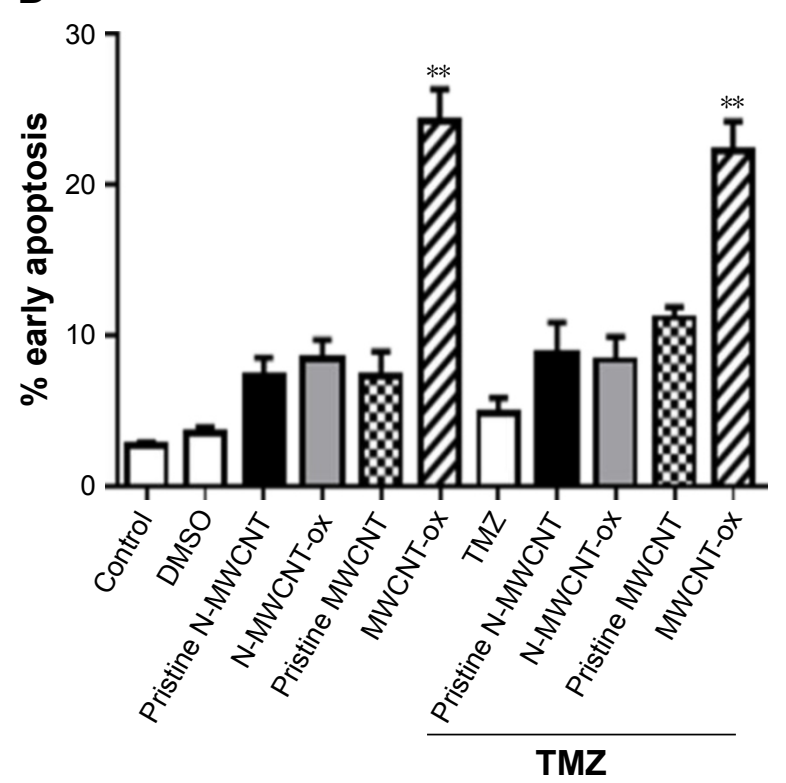

Figure 6 Effect of TMZ or MWCNTs on apoptosis induction in malignant RG2 glioma cells in vitro.

Notes: Tumor cells were seeded at a density of $3 \times 10^{5}$ cells per well $(1 \mathrm{~mL})$ in six-well flat-bottomed plates and incubated overnight at $37^{\circ} \mathrm{C}$. After exposure to TMZ $(10 \mathrm{mM})$ and treatments with MWCNTs $(50 \mu \mathrm{g} / \mathrm{mL})$ for $24 \mathrm{~h}$, the cells were trypsinized. Results show the mean \pm SEM of three independent experiments of viable cells $(\mathbf{A})$, necrotic cells (B), late apoptosis (C) and apoptosis (D). $* P<0.01$ vs control and $* * P<0.00$ I vs control.

Abbreviations: TMZ, temozolomide; MWCNT, multiwalled carbon nanotube; N-MWCNT, nitrogen-doped MWCNT; N-MWCNT-ox, acid-treated nitrogen-doped MWCNT; MWCNT-ox, acid-treated MWCNT. 


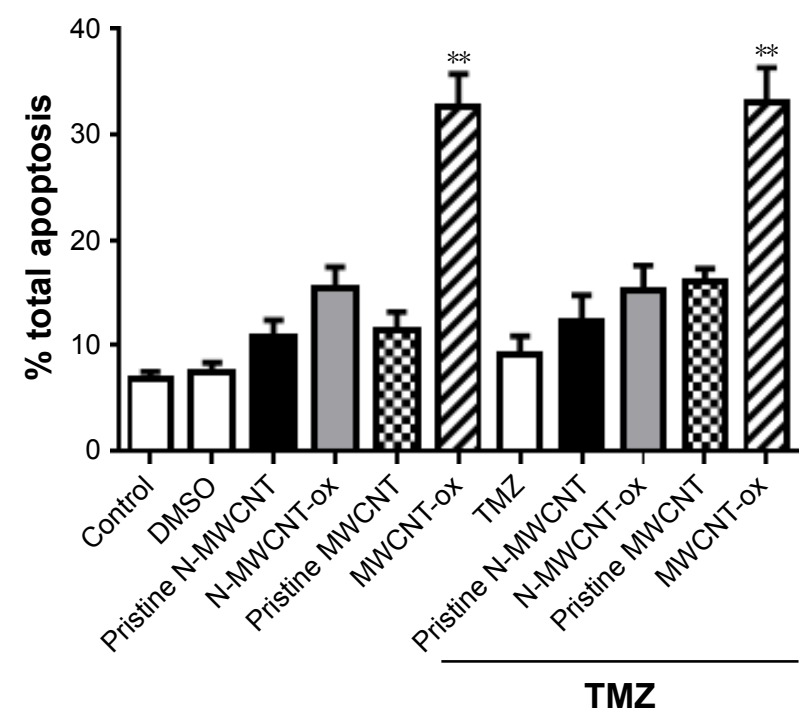

Figure 7 Effect of TMZ or MWCNTs on total apoptosis induction in malignant RG2 glioma cells in vitro.

Notes: Tumor cells were seeded at a density of $3 \times 10^{5}$ cells per well $(1 \mathrm{~mL})$ in sixwell flat-bottomed plates and incubated overnight at $37^{\circ} \mathrm{C}$. After exposure to $\mathrm{TMZ}$ (10 mM) and MWCNTs $(50 \mu \mathrm{g} / \mathrm{mL})$ for $24 \mathrm{~h}$, the cells were trypsinized, and the number of total apoptotic cells was determined by flow cytometry. Results show the mean \pm SEM of three independent experiments. $* * P<0.00$ I vs control.

Abbreviations: TMZ, temozolomide; MWCNT, multiwalled carbon nanotube; N-MWCNT, nitrogen-doped MWCNT; N-MWCNT-ox, acid-treated nitrogendoped MWCNT; MWCNT-ox, acid-treated MWCNT.

with TMZ. In the MWCNT-ox group, cell replication was arrested in the G2-M phase. No differences over the cell cycle were seen compared with the other MWCNTs. These results indicate that the main mechanism of MWCNTs

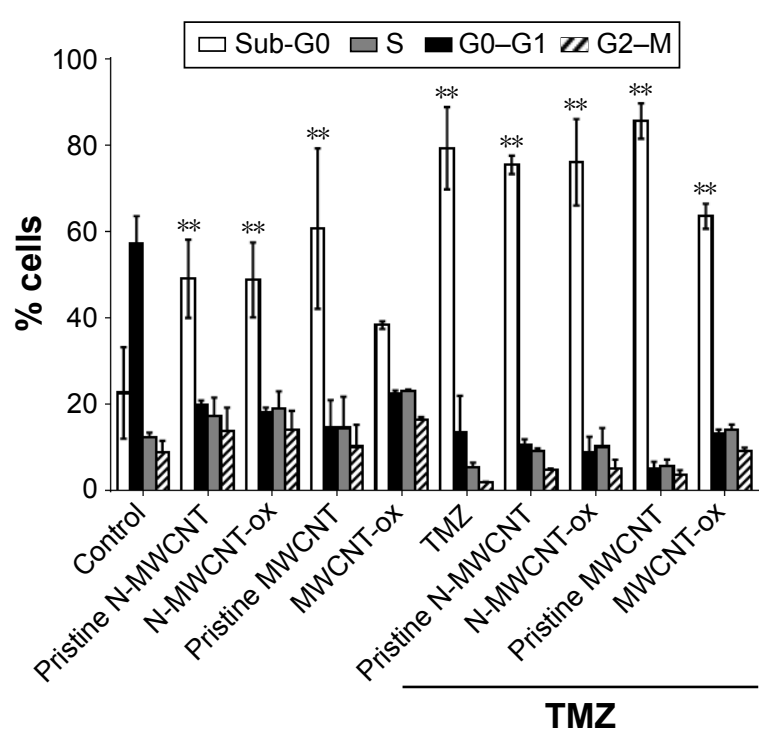

Figure 8 TMZ treatment maximizes the cell cycle arrest by MWCNTs in RG2 glioma cells.

Notes: RG2 glioma cells were treated with $50 \mu \mathrm{g}$ of MWCNTs, TMZ or MWCNTs plus TMZ. Graphs show mean \pm SEM of RG2 glioma cells in sub-G0, G0-GI, S and G2-M cell cycle stage. The percentage of dead cells was determined by FACS using propidium iodide stain. $* * P<0.001$ vs control.

Abbreviations: TMZ, temozolomide; MWCNT, multiwalled carbon nanotube; N-MWCNT, nitrogen-doped MWCNT; N-MWCNT-ox, acid-treated nitrogendoped MWCNT; MWCNT-ox, acid-treated MWCNT. treatment is not through cell cycle arrest, with the exception of MWCNT-ox.

\section{Cellular dysfunction was not related with ROS production}

MTT reduction assay was used to verify whether MWCNTs induced cellular dysfunction. After $24 \mathrm{~h}$ of treatment, a significant reduction was observed in all groups treated with CNTs or CNTs plus TMZ. The main diminution in MTT was seen in both groups treated with MWCNTs-ox (Figure 9).

Due to the possibility that MWCNTs can induce the production of ROS through the Fenton reaction, we performed an ROS analysis using DCFH-DA at different periods of treatment. The results did not show significant changes, that is, neither extracellular nor intracellular ROS production (Figures 10 and 11). However, a discrete decrease of intracellular ROS was found in the MWCNT-ox, TMZ and MWCNT-ox plus TMZ groups (Figure 10); nevertheless, this change did not achieve statistical significance $(P=0.80)$.

\section{MWCNTs induced apoptosis in RG2}

\section{cells promoting reduction in the}

\section{mitochondrial membrane potential}

Due to the apoptosis induced by MWCNTs, we determined the possible reduction of mitochondrial membrane potential $(\Delta \Psi \mathrm{m})$ induced by MWCNTs. Data analysis demonstrated

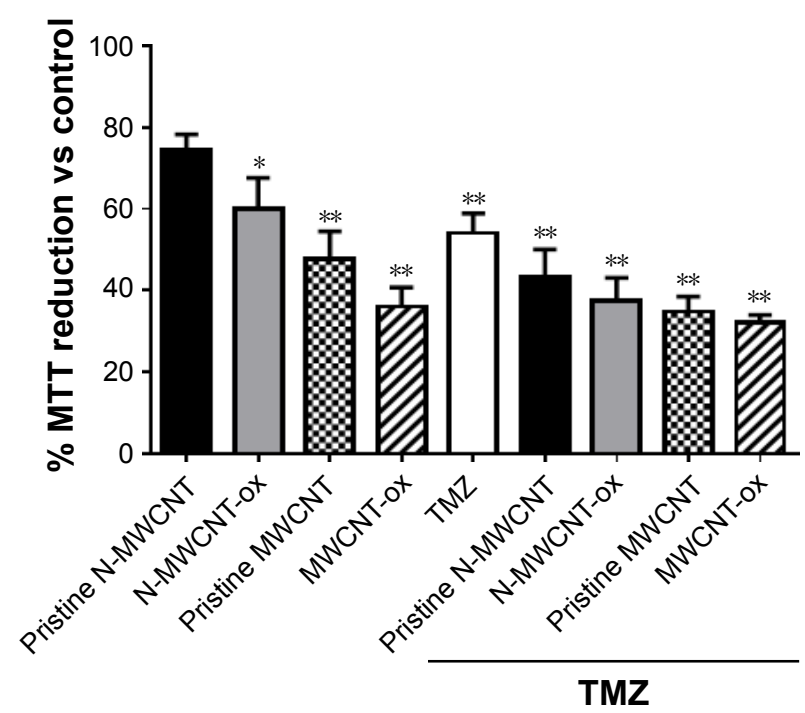

Figure $9 \mathrm{TMZ}$ treatment maximizes the cellular dysfunction by MWCNTs in RG2 glioma cells.

Notes: RG2 glioma cells were treated with $50 \mu \mathrm{g} / \mathrm{mL}$ of MWCNTs, TMZ or MWCNTs plus TMZ. Graph shows mean \pm SEM of MTT reduction in RG2 glioma cells. Malignant RG2 glioma cells $\left(I \times 10^{5}\right)$ were seeded in 96 -well plates in contact with the different types of MWCNTs; after $24 \mathrm{~h}$ of treatment, MTT reduction was assessed. $* P<0.01$ vs control and $* * P<0.001$ vs control.

Abbreviations: TMZ, temozolomide; MWCNT, multiwalled carbon nanotube; N-MWCNT, nitrogen-doped MWCNT; N-MWCNT-ox, acid-treated nitrogendoped MWCNT; MWCNT-ox, acid-treated MWCNT. 
$30 \mathrm{~min}$

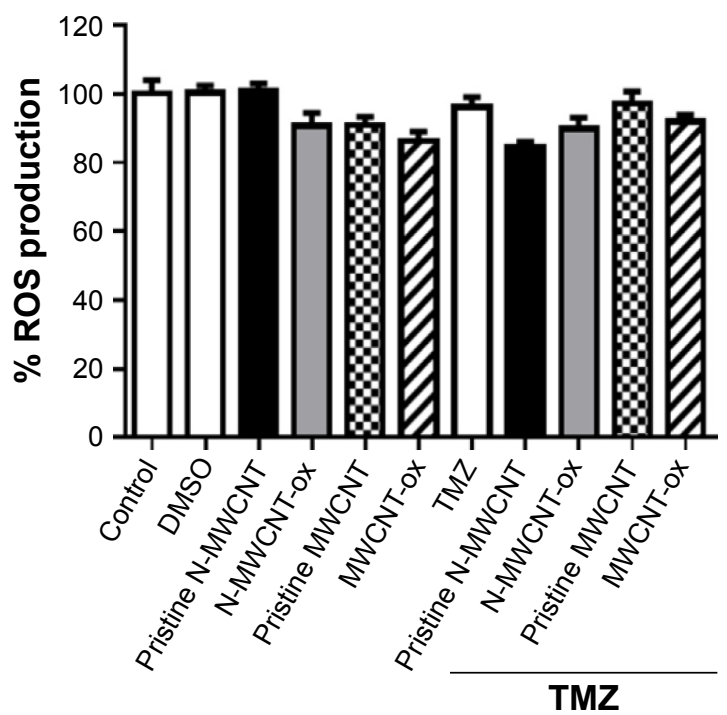

$3 \mathrm{~h}$

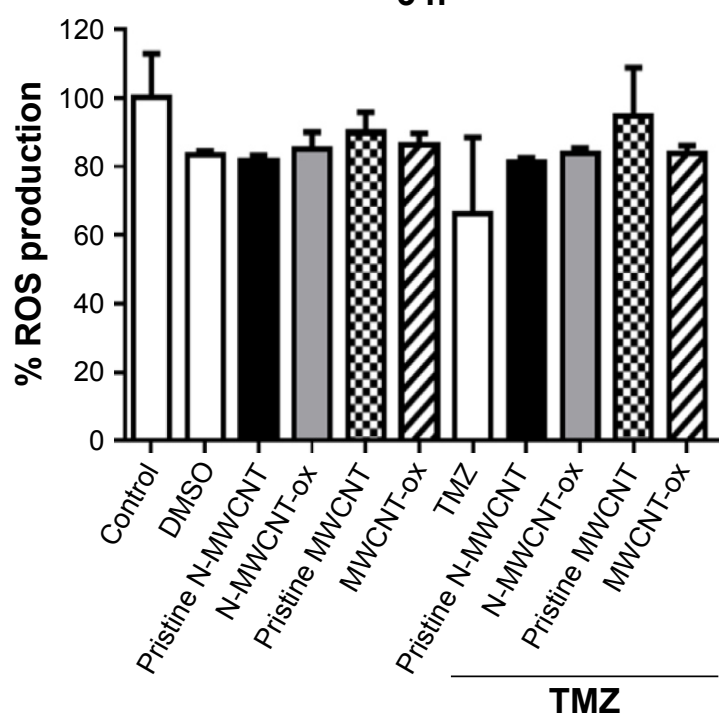

$1 \mathrm{~h}$

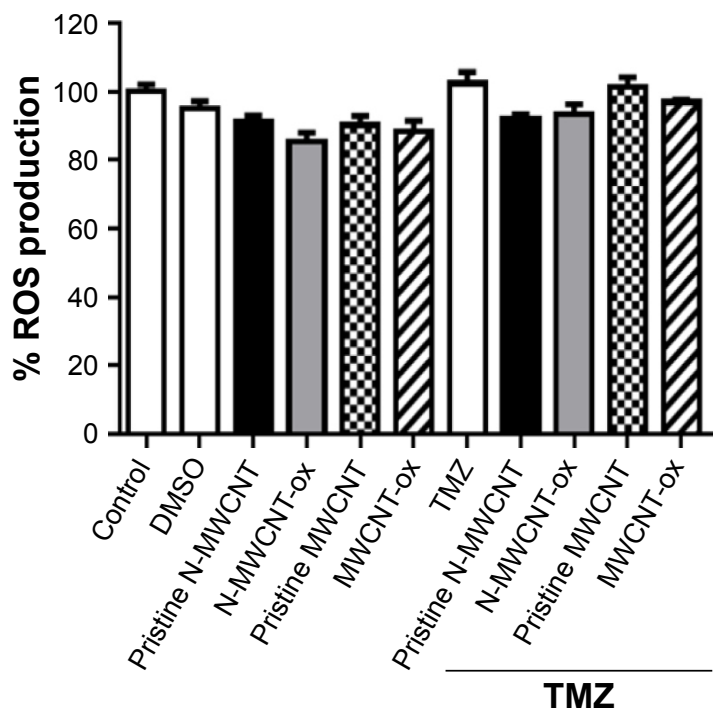

$6 \mathrm{~h}$

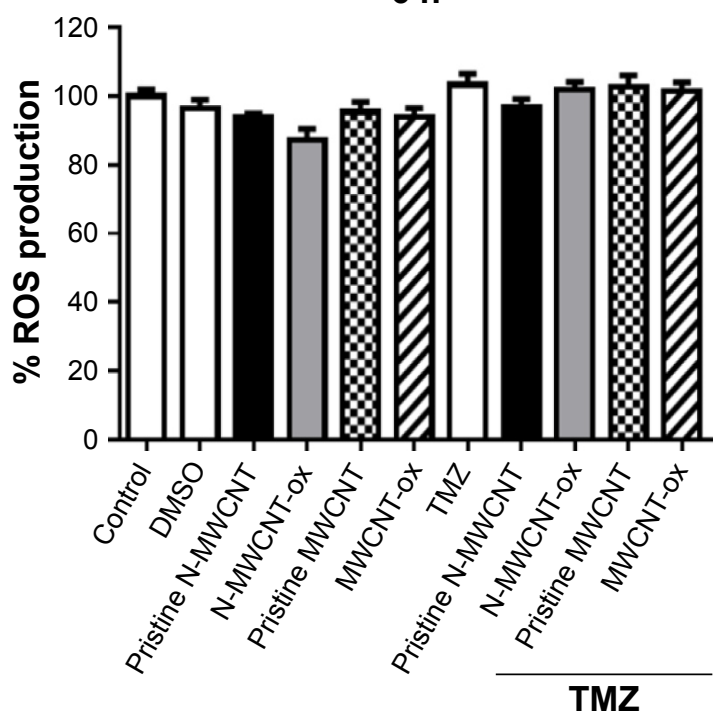

Figure 10 ROS production induced by MWCNTs.

Notes: RG2 glioma cells were treated with $50 \mu \mathrm{g} / \mathrm{mL}$ of MWCNTs, TMZ or MWCNTs plus TMZ. Graph shows mean \pm SEM of ROS production. Malignant RG2 glioma cells $\left(I \times 10^{6}\right)$ were seeded in six-well plates in contact with the different CNTs; after 30, 60, 180 and 360 min, ROS production was assessed. No significant changes were seen between treatments.

Abbreviations: ROS, reactive oxygen species; MWCNT, multiwalled carbon nanotube; TMZ, temozolomide; CNTs, carbon nanotubes; N-MWCNT, nitrogen-doped MWCNT; N-MWCNT-ox, acid-treated nitrogen-doped MWCNT; MWCNT-ox, acid-treated MWCNT.

a significant decrease of $\Delta \Psi \mathrm{m}$ in all groups treated with MWCNTs and their combination with TMZ except for the pristine MWCNT group. The greatest effect was found in the MWCNT-ox plus TMZ group (Figure 12).

\section{MWCNTs induced apoptosis but no} autophagy in RG2 malignant glioma cells Radiation or chemotherapeutic agents such as tamoxifen, arsenic trioxide or TMZ induce autophagy but not apoptosis in various cancer cells, including malignant glioma cells. ${ }^{29}$ To evaluate whether TMZ, MWCNTs or their combination induces alterations similar to autophagy, RG2 cells were exposed for $24 \mathrm{~h}$ to TMZ (100 mM), MWCNTs $(50 \mu \mathrm{g} / \mathrm{mL})$ or TMZ plus MWCNTs. Afterwards, the cells were stained with anti-LC3, and analyzed by flow cytometry. As shown in Figure 13, no significant changes were observed for any treatment.

MWCNTs did not induce inflammation or systemic toxicity and were endocytosed by malignant glioma cells in vivo

To observe the distribution of MWCNTs in vivo, they were injected into both healthy and tumoral tissues from rats 


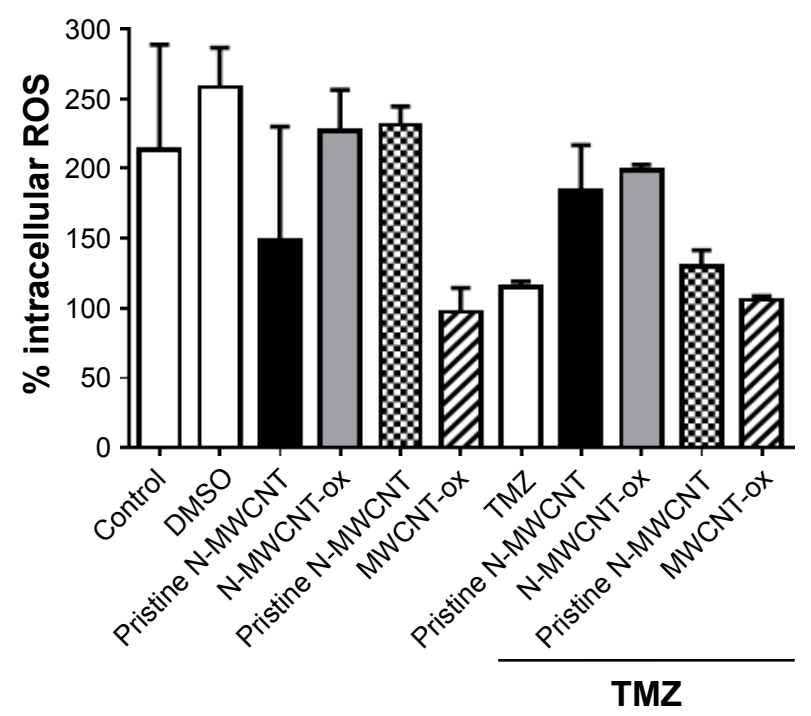

Figure I I Intracellular ROS production induced by MWCNTs.

Notes: RG2 glioma cells were treated with $50 \mu \mathrm{g} / \mathrm{mL}$ of MWCNTs, TMZ or MWCNTs plus TMZ. Graph shows mean \pm SEM of intracellular ROS production by glioma cells. RG2 glioma cells $\left(I \times 10^{6}\right)$ were seeded in six-well plates for treatment; after $60 \mathrm{~min}$, intracellular ROS production was assessed by FACS. No significant changes were seen between treatments.

Abbreviations: ROS, reactive oxygen species; MWCNT, multiwalled carbon nanotube; TMZ, temozolomide; N-MWCNT, nitrogen-doped MWCNT; N-MWCNT-ox, acid-treated nitrogen-doped MWCNT; MWCNT-ox, acid-treated MWCNT.

(Figure 14). The four types of MWCNTs did not cause inflammation remaining in the site of injection even after 30 days in healthy tissue. In contrast, in tumoral tissue, we observed a decrease in the cumulus of MWCNTs; this effect was greater

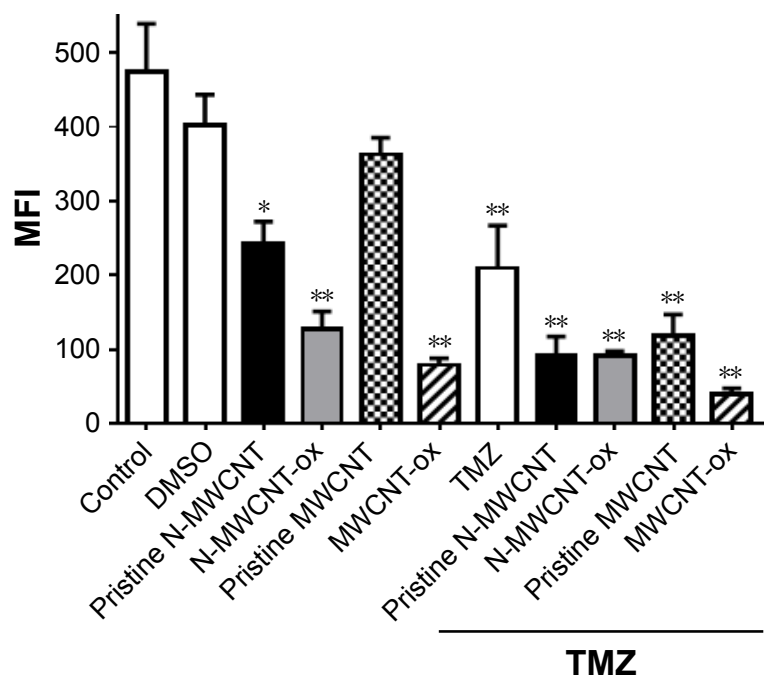

Figure 12 TMZ treatment increases MWCNTs-induced mitochondrial dysfunction in RG2 glioma cells.

Notes: RG2 glioma cells were treated with $50 \mu \mathrm{g} / \mathrm{mL}$ of MWCNTs, TMZ or MWCNTs plus TMZ. Graph shows the MFI \pm SEM in RG2 glioma cells. RG2 glioma cells $\left(I \times \mid 0^{6}\right)$ were seeded in six-well plates for the different treatments; after $24 \mathrm{~h}$ of treatment, mitochondrial membrane potential $(\Delta \Psi \mathrm{m})$ was determined by FACS. $* P<0.01$ vs control and $* * P<0.001$ vs control.

Abbreviations: TMZ, temozolomide; MWCNT, multiwalled carbon nanotube; MFI, mean fluorescence intensity; N-MWCNT, nitrogen-doped MWCNT; N-MWCNTox, acid-treated nitrogen-doped MWCNT; MWCNT-ox, acid-treated MWCNT.

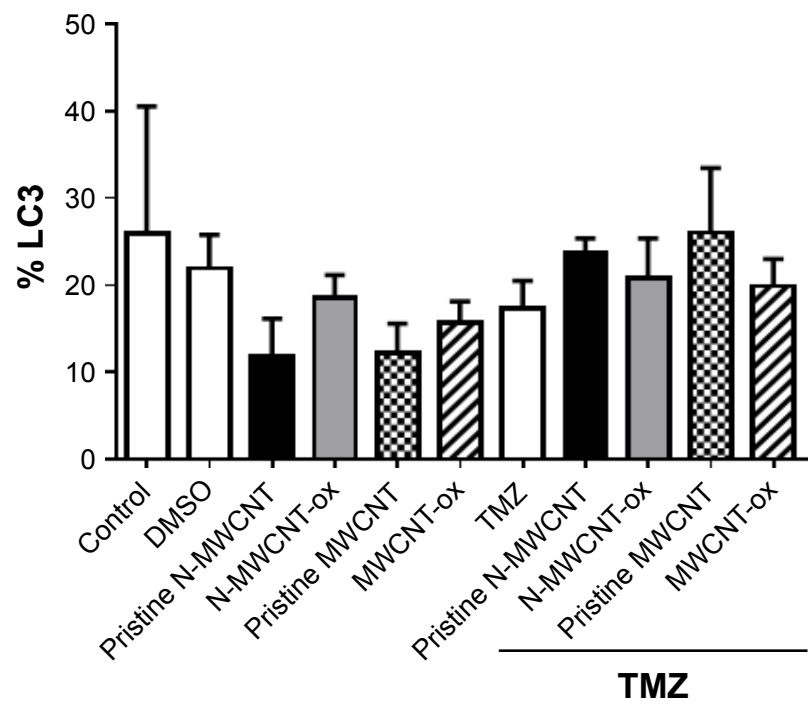

Figure 13 Effect of TMZ or MWCNTs on autophagy induction in malignant RG2 glioma cells.

Notes: Tumor cells were seeded at a density of $1 \times 10^{6}$ cells per well $(1 \mathrm{~mL})$ in sixwell flat-bottomed plates and incubated overnight at $37^{\circ} \mathrm{C}$. After exposure to $\mathrm{TMZ}$ (10 mM) and MWCNTs $(50 \mu \mathrm{g} / \mathrm{mL})$ for $24 \mathrm{~h}$, the cells were trypsinized, and the percentage of LC3+ cells was measured by flow cytometry. The figure shows the means \pm SEM of three independent experiments.

Abbreviations: TMZ, temozolomide; MWCNT, multiwalled carbon nanotube; MFI, mean fluorescence intensity; N-MWCNT, nitrogen-doped MWCNT; N-MWCNTox, acid-treated nitrogen-doped MWCNT; MWCNT-ox, acid-treated MWCNT.

in the MWCNT-ox group, and the highest dispersion of nanoparticles and their internalization were observed in tumoral cells. Notably, the animals injected with any of the four types of MWCNTs did not show signs of local or systemic toxicity; blood count, blood chemistry and hepatic and cardiac functions showed no evidence of drug-induced toxicity (data not shown).

\section{N-MWCNTs-ox increased survival of rats bearing intracerebral RG2 glioma}

To determine if the MWCNTs increased survival of rats intracranially implanted with RG2 cells, we measured survival of 10 rats from each group intratumorally injected with the different MWCNTs 7 days after the inoculation of RG2 cells. A statistically significant increase in survival was seen in the group treated with N-MWCNTs-ox $(P=0.015)$, but not in different groups treated with the other MWCNTs (Figure 15).

\section{Discussion}

Nanotubes have been used in recent years as drug carriers, as well as diagnostic and analytical biosensors. ${ }^{35}$ Our results suggest that MWCNTs may also be used for treatment of brain tumors due to their nanostructure, shape and biological properties, which give them the ability to cross the bloodbrain barrier. It has been described that CNTs injected systemically are internalized in brain cells by phagocytic 


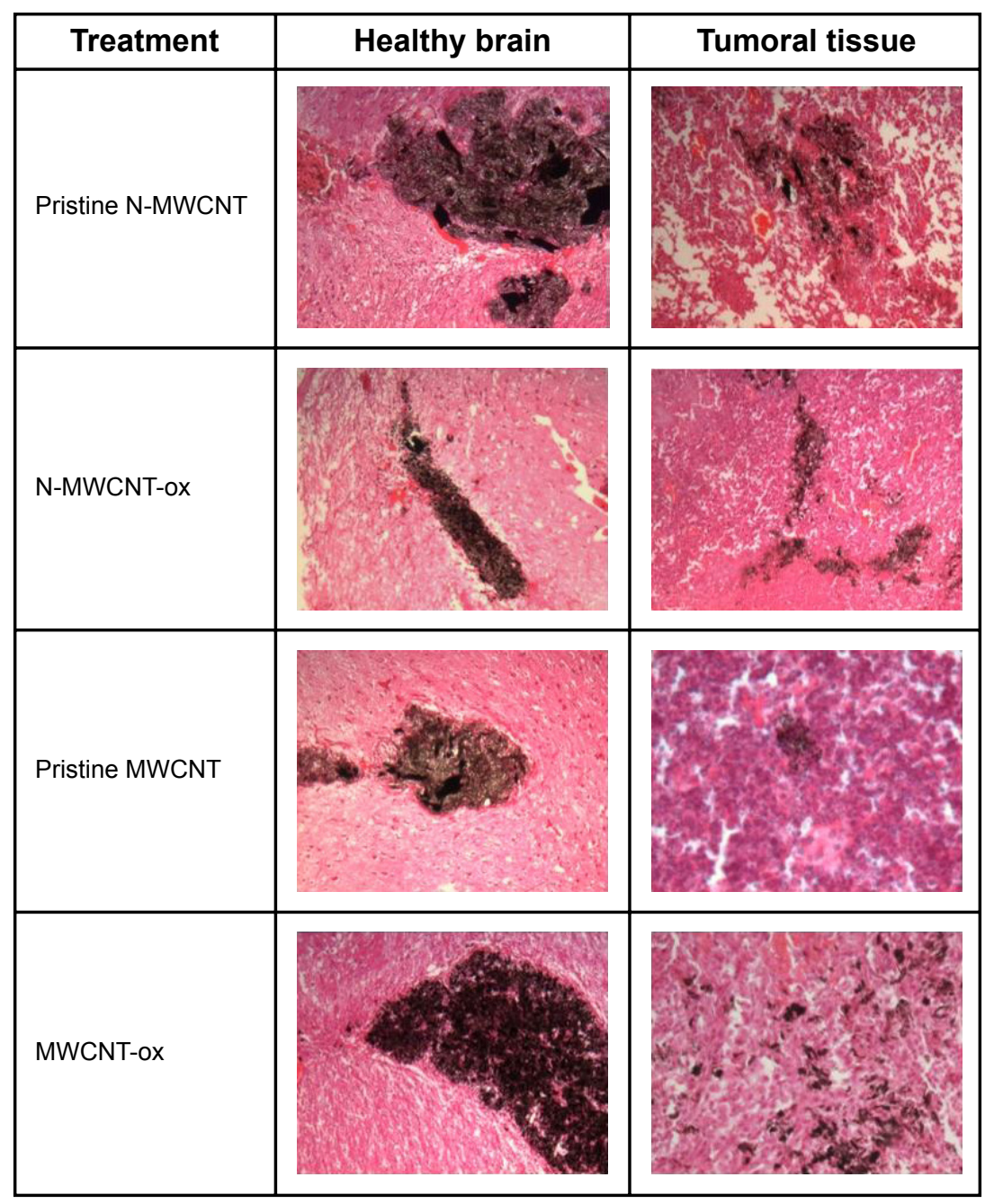

Figure 14 Histological sections of healthy rat brain and tumoral tissue from the left side of brain after intratumoral injection of MWCNTs (magnification 200x). Notes: No signs of inflammation by mononuclear cell infiltration were seen in all treated tissues. MWCNTs were more concentrated in healthy brain compared with tumoral tissue.

Abbreviations: MWCNT, multiwalled carbon nanotube; N-MWCNT, nitrogen-doped MWCNT; N-MWCNT-ox, acid-treated nitrogen-doped MWCNT; MWCNT-ox, acid-treated MWCNT.

mechanisms, achieving cytoplasmic location within the cells $24 \mathrm{~h}$ after injection. ${ }^{36}$

In this study, we analyzed the potential of four different CNTs to induce cell death in GBM cells. MWCNTs were obtained using the AACVD technique which allows producing clean and homogenous MWCNTs (Figures 1 and S1). The MWCNTs used in this study induced cell death in both astrocytes and cultured RG2 cells at all concentrations used (Figures 2 and 3), as has been previously reported. ${ }^{37-39}$ After observing the results, we decided to use the $50 \mu \mathrm{g} / \mathrm{mL}$ dose for further experiments; at this concentration, all MWCNTs induced a significant percentage of cell death. Considering that the standard treatment for GBM consists in surgical resection accompanied by radiotherapy and chemotherapy with TMZ, ${ }^{40,41}$ the next step was to use MWCNTs in combination with TMZ. We found an increase in cell death when all MWCNTs were used in combination with TMZ, suggesting the potential of MWCNTs as a therapeutic agent in combination with the standard chemotherapy in GBM patients. Similar results have been reported in the study by Ouyang et al, in which SWCNTs were administered in combination with TMZ; the authors attributed this effect to immune modulation, potentiation of $\mathrm{TMZ}$ and the covering of nanotubes with oligodeoxynucleotides $\mathrm{CpG}^{42}$ It is important to consider that the effect of CNTs is dependent on intrinsic factors such as formulation, production and endocytosis capacity. ${ }^{38}$ This investigation evaluated the effect of the MWCNTs plus TMZ in malignant glial cells and MWCNTs bioavailability in RG2 glioma cells: functionalized MWCNTs were more efficiently endocytosed by RG2 cells than nonfunctionalized MWCNTs. From the FACS analysis, we learned that in vitro cells treated with functionalized MWCNTs alone or in combination with TMZ increased in size compared with control cells (Figure 5A and B). In this context, Han et al 


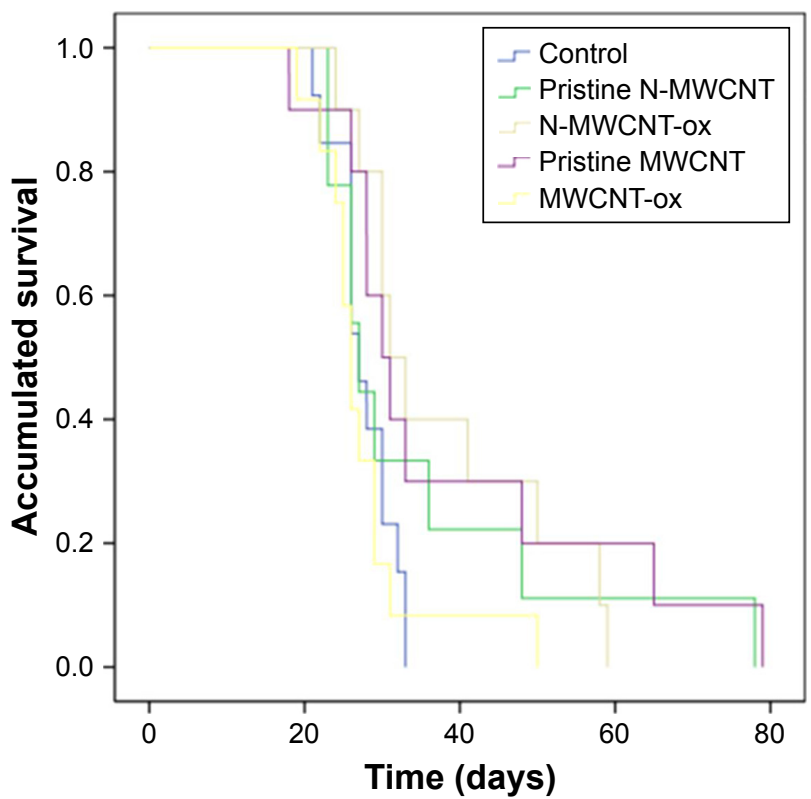

Figure I5 Kaplan-Meier survival plot of rats bearing intracranial RG2 glioma after intratumoral administration of different MWCNTs $(50 \mu \mathrm{g} / 10 \mu \mathrm{L}$ at day 2 postimplant).

Notes: Prolonged survival was seen in rats bearing intracranial RG2 glioma treated with N-MWCNT-ox. The figure shows the survival curves and Kaplan-Meier survival analysis of rats implanted with RG2 $\left(I \times \mid 0^{6}\right.$ cells/rat $)$ and treated with MWCNTs $(n=10)$.

Abbreviations: MWCNT, multiwalled carbon nanotube; N-MWCNT-ox, acidtreated nitrogen-doped MWCNT; N-MWCNT, nitrogen-doped MWCNT; MWCNT-ox, acid-treated MWCNT.

reported that size variations in CNTs could induce different rates of cellular damage in rats bearing $\mathrm{C} 6$ glioma cells. ${ }^{43}$ These effects might be explained by the functionalization process that allows better dispersion of CNTs, improving their bioavailability (Figure 5A). However, the endocytosis ability was not affected by the addition of TMZ (Figure 5B). Surface characteristics of functionalized MWCNTs, such as the degree of hydrophobicity and protein modification, are important for cell internalization. ${ }^{20,44}$ Our study showed that nanoparticles functionalized with Fe were phagocytosed more efficiently, thus increasing their cellular damage. Similarly, Vakarelski et al reported that CNTs penetrate membranes of living cells. ${ }^{45}$ Several reports have shown that the CNTs are endocytosed preferably by neoplastic cells. ${ }^{46-50}$ The CNTs are endocytosed via tip recognition through receptor binding ${ }^{51}$ these receptors are commonly overexpressed in cancer cells, which explains why GBM cells endocytose high amounts of CNTs (Figure 5A and B). ${ }^{52}$

In this study, we observed an increase in death in cells treated with MWCNTs-ox and with MWCNTs-ox plus TMZ as evidenced by 1) increase in the number of Annexin $\mathrm{V}+$ cells (in early and in late apoptosis) (Figures 6 and 7), 2) decrease in the mitochondrial membrane potential $\Delta \Psi \mathrm{m}$ (Figure 12) and 3) reduction in the cellular functionality
(Figure 9). Various hypotheses might be formulated to explain the induction of cell death by MWCNTs; one suggests that CNTs induce the creation of adducts and/or damage at DNA level. Lindberg et al have suggested that MWCNTs efficiently interact with biomolecules by stimulating the formation of non-covalent conjugates (protein-MWCNT); such conjugates may be transported inside mammalian cells via endocytosis. ${ }^{53}$ Once these conjugates have been freed by the lysosomes, they are internalized into cytoplasm interfering with biological functions, which becomes evident by the induction of apoptosis and the expression of the BCL-2 protein family; in turn, when Bcl-2 is expressed, it causes the release of cytochrome $\mathrm{C}$ from the mitochondria to the cytosol. ${ }^{54,55}$

To evaluate how MWCNTs could induce cellular damage, we analyzed cell cycle progression. We found an increase in the sub-G0 peak in every group of CNTs in combination with TMZ due to DNA fragmentation. The only group that showed arrest in the G2-M phase was group 4 (MWCNTs-ox) (Figure 8). These results suggest that the process of cell death was mediated mainly by increase in apoptosis and arrest in the G2-M phase of the cell cycle, as has been reported in leukemia cells, where treatment with CNTs induced a decrease in cell growth associated with cell cycle arrest. Similar results have been described in peripheral blood lymphocytes, where CNTs block the progression of the cell cycle by inducing an arrest in the G0-G1 phase. ${ }^{56}$ In vitro studies have demonstrated that CNTs block G1 phase in NRK-52E rat kidney epithelial cells. ${ }^{57}$ Additional studies have shown that CNTs induce arrest in G1-S phase of the cell cycle in BEAS-2B bronchial epithelial cells. ${ }^{58}$

Induction of oxidative stress seems to be fundamental for the cytotoxic effects of MWCNTs. Once inside the cell, these nanomaterials seem to induce oxidative stress causing an imbalance between oxidant and antioxidant processes. This effect may increase the concentrations of cytosolic calcium or cause a translocation of transcription factors to the nucleus which regulate pro-inflammatory genes, such as TNF- $\alpha$ or iNOS. ${ }^{59}$ The increase in oxidative stress could modify proteins, lipids and nucleic acids, which, in the long-term stimulate the antioxidant defense response or even induce cellular death. ${ }^{53,60}$ Some studies suggest that cytotoxicity induced by CNTs may be the result of ROS generated from the iron catalyzer, probably as a result of the Fenton reaction; ${ }^{61}$ however, in our study, we did not find changes in the production of ROS (Figures 10 and 11). Also, studies in leukemia cells did not find significant differences in the ROS levels between treated and untreated cells,${ }^{62}$ suggesting 
that apoptosis induction is not a result of the ROS induction process. Another possible mechanism of cell death induced by CNTs is autophagy; nevertheless, our results did not show significant changes in the percentage of cells expressing LC3 light chain (Figure 13).

To determine whether MWCNTs treatment induces toxic effects in healthy rats, we injected $50 \mu \mathrm{g} / 10 \mu \mathrm{L}$ of MWCNTs/ PBS. After 21 days, no significant changes were observed in blood biochemical parameters (data not shown). Also, no inflammation or diffusion of MWCNTs into healthy tissue was seen at the site of injection in rats treated with any of the four MWCNTs (Figure 14). In contrast, when MWCNTs were administrated within tumoral tissue, we observed diffusion of the MWCNTs that could be explained by the increased capacity of tumor cells to endocytose either the CNTs or the macrophages and immune cells infiltrating the tumor (Figure 14). ${ }^{52,63}$

To know whether the MWCNTs were able to induce cell death and increase the survival of rats implanted with intracerebral GBM, four types of MWCNTs were intratumorally injected. The results showed a significant increase in survival in animals treated with N-MWCNTs-ox ( 38 vs 27 days, $P=0.015$ ) compared to controls. None of the other CNTs tested improved survival in rats with intracerebral glioma. However, even when MWCNTs-ox had shown increased cell death induction in RG2 cells in vitro, this treatment did not produce a significant impact in survival in vivo, which could be explained by its toxicity and lack of selectivity. These nanoparticles induced cell death in both healthy and tumoral cells, but did not improve the mean survival of treated animals. Several reports have shown that MWCNTs-ox possess pro-inflammatory activity and are endocytosed by healthy cells, inducing lysosomal dysfunction and mitochondrial damage in both healthy and tumoral cells. ${ }^{64-66}$ Conversely, N-MWCNTs-ox and MWCNTs-ox were more easily endocytosed by tumoral cells and were less toxic. ${ }^{52}$ It is possible that these nanoparticles are better tolerated, leading to minor intracerebral inflammation and increase in survival.

\section{Conclusion}

The use of nanotechnology in medicine (nano-medicine) is rapidly spreading. In recent years, nanomaterials have been tested in several ways, either as carriers for other components (such as drugs) or as a primary treatment for several diseases. In this study, we investigated the possible use of CNTs as a therapeutic option for GB. Our findings suggested that functionalized multilayer CNTs, alone or in combination with TMZ, increase the induction of cell death by cell cycle arrest and activation of apoptosis.

This represents an initial approach to an alternative treatment for GB; although our results are promising, more studies are necessary to gain more experience and find out whether they can be used in human trials. The potential adverse effects of delivering nanostructures to the GBM in brain where healthy and neoplastic cells coexist must be evaluated.

\section{Acknowledgments}

This work was supported by grants CB180851 (from Consejo Nacional de Ciencia y Tecnología, Mexico, CONACYT) and FOSSIS 262010. EMS also thanks CONACYT for the partial support from grant 220744.

\section{Author contributions}

All authors contributed toward data analysis, drafting and critically revising the paper and agree to be accountable for all aspects of the work.

\section{Disclosure}

The authors report no conflicts of interest in this work.

\section{References}

1. Berens ME, Rutka JT, Rosenblum ML. Brain tumor epidemiology, growth, and invasion. Neurosurg Clin N Am. 1990;1(1):1-18.

2. Omuro AM, Faivre S, Raymond E. Lessons learned in the development of targeted therapy for malignant gliomas. Mol Cancer Ther. 2007;6(7): 1909-1919.

3. Stupp R, Mason WP, van den Bent MJ, et al; European Organisation for Research and Treatment of Cancer Brain Tumor and Radiotherapy Groups; National Cancer Institute of Canada Clinical Trials Group. Radiotherapy plus concomitant and adjuvant temozolomide for glioblastoma. N Engl J Med. 2005;352(10):987-996.

4. Pinto LW, Araujo MB, Vettore AL, et al. Glioblastomas: correlation between oligodendroglial components, genetic abnormalities, and prognosis. Virchows Arch. 2008;452(5):481-490.

5. Huang S, Ming T, Lin Y, et al. Ultrasmall mode volumes in plasmonic cavities of nanoparticle-on-mirror structures. Small. 2016;12(37): 5190-5199.

6. Liu Z, Liu Y, Peng D. Hydroxylation of multi-walled carbon nanotubes: enhanced biocompatibility through reduction of oxidative stress initiated cell membrane damage, cell cycle arrestment and extrinsic apoptotic pathway. Environ Toxicol Pharmacol. 2016;47:124-130.

7. Hernández-Pedro NY, Rangel-Lopez E, Magaña-Maldonado R, et al. Application of nanoparticles on diagnosis and therapy in gliomas. Biomed Res Int. 2013;2013:351031.

8. Jiang W, Wang Q, Qu X, et al. Effects of charge and surface defects of multi-walled carbon nanotubes on the disruption of model cell membranes. Sci Total Environ. 2016;574:771-780.

9. Hong G, Diao S, Antaris AL, Dai H. Carbon nanomaterials for biological imaging and nanomedicinal therapy. Chem Rev. 2015;115(19): 10816-10906.

10. Sayes CM, Liang F, Hudson JL, et al. Functionalization density dependence of single-walled carbon nanotubes cytotoxicity in vitro. Toxicol Lett. 2006;161(2):135-142. 
11. Coccini T, Roda E, Sarigiannis DA, et al. The degree of functionalization affects in vitro cytotoxicity of multi-walled carbon nanotubes (CNTs). Toxicol Lett. 2009;189S:S57-S273.

12. Yao HJ, Sun L, Liu Y, et al. Monodistearoylphosphatidylethanolaminehyaluronic acid functionalization of single-walled carbon nanotubes for targeting intracellular drug delivery to overcome multidrug resistance of cancer cells. Carbon. 2016;96:362-376.

13. Tahermansouri H, Ghobadinejad H. Functionalization of short multiwalled carbon nanotubes with creatinine and aromatic aldehydes via microwave and thermal methods and their influence on the MKN45 and MCF7 cancer cells. C R Chim. 2013;16:838-844.

14. Wang N, Feng Y, Zeng L, Zhao Z, Chen T. Functionalized multiwalled carbon nanotubes as carriers of ruthenium complexes to antagonize cancer multidrug resistance and radioresistance. ACS Appl Mater Interfaces. 2015;7(27):14933-14945.

15. Graham EG, MacNeill CM, Levi-Polyachenko NH. Quantifying folic acid-functionalized multi-walled carbon nanotubes bound to colorectal cancer cells for improved photothermal ablation. J Nanopart Res. 2013;15:1649.

16. Iancu C, Mocan L, Bele C, et al. Enhanced laser thermal ablation for the in vitro treatment of liver cancer by specific delivery of multiwalled carbon nanotubes functionalized with human serum albumin. Int $J$ Nanomedicine. 2011;6:129-141.

17. Lacerda L, Soundararajan A, Singh R, et al. Dynamic imaging of functionalized multi-walled carbon nanotube systemic circulation and urinary excretion. Adv Mater. 2008;20(2):223-230.

18. Marega R, De Leo F, Pineux F, et al. Functionalized Fe-filled multiwalled carbon nanotubes as multifunctional scaffolds for magnetization of cancer cells. Adv Funct Mater. 2013;23(25):3173-3184.

19. de Faria PC, dos Santos LI, Coelho JP, et al. Oxidized multiwalled carbon nanotubes as antigen delivery system to promote superior CD8(+) T cell response and protection against cancer. Nano Lett. 2014; 14(9):5458-5470.

20. Kostarelos K, Lacerda L, Pastorin G, et al. Cellular uptake of functionalized carbon nanotubes is independent of functional group and cell type. Nat Nanotechnol. 2007;2(2):108-113.

21. Seoane M, Iglesias P, Gonzalez T, et al. Retinoblastoma loss modulates DNA damage response favoring tumor progression. PLoS One. 2008;3(11):e3632.

22. Garcia E, Limon D, Perez-De La Cruz V, et al. Lipid peroxidation, mitochondrial dysfunction and neurochemical and behavioural deficits in different neurotoxic models: protective role of S-allylcysteine. Free Radic Res. 2008;42(10):892-902.

23. Pérez-De La Cruz V, González-Cortés C, Galván-Arzate S, et al. Excitotoxic brain damage involves early peroxynitrite formation in a model of Huntington's disease in rats: protective role of iron porphyrinate 5,10,15,20-tetrakis (4-sulfonatophenyl)porphyrinate iron (III). Neuroscience. 2005;135(2):463-474.

24. Pietra G, Mortarini R, Parmiani G, Anichini A. Phases of apoptosis of melanoma cells, but not of normal melanocytes, differently affect maturation of myeloid dendritic cells. Cancer Res. 2001;61(22):8218-8226.

25. Abarca-Rojano E, Muñiz-Hernández S, Moreno-Altamirano MM, Mondragón-Flores R, Enriquez-Rincón F, Sánchez-García FJ. Re-organization of mitochondria at the NK cell immune synapse. Immunol Lett. 2009;122(1):18-25.

26. Kabeya Y, Mizushima N, Ueno T, et al. LC3, a mammalian homologue of yeast Apg8p, is localized in autophagosome membranes after processing. EMBO J. 2000;19(21):5720-5728.

27. Klionsky DJ, Abdelmohsen K, Abe A, et al. Guidelines for the use and interpretation of assays for monitoring autophagy (3rd edition). Autophagy. 2016;12(1):1-222.

28. Munafó DB, Colombo MI. A novel assay to study autophagy: regulation of autophagosome vacuole size by amino acid deprivation. J Cell Sci. 2001;114(Pt 20):3619-3629.

29. Kanzawa T, Kondo Y, Ito H, Kondo S, Germano I. Induction of autophagic cell death in malignant glioma cells by arsenic trioxide. Cancer Res. 2003;63(9):2103-2108.
30. Paglin S, Hollister T, Delohery T, et al. A novel response of cancer cells to radiation involves autophagy and formation of acidic vesicles. Cancer Res. 2001;61(2):439-444.

31. Kanzawa T, Ito H, Kondo Y, Kondo S. Current and future gene therapy for malignant gliomas. J Biomed Biotechnol. 2003;2003(1):25-34.

32. Ali SF, LeBel CP, Bondy SC. Reactive oxygen species formation as a biomarker of methylmercury and trimethyltin neurotoxicity. Neurotoxicology. 1992;13(3):637-648.

33. Herrera-Mundo N, Sitges M. Mechanisms underlying striatal vulnerability to 3-nitropropionic acid. J Neurochem. 2010;114(2):597-605.

34. Kobayashi N, Allen N, Clendenon NR, Ko LW. An improved rat braintumor model. J Neurosurg. 1980;53(6):808-815.

35. Shi X, Wang SH, Shen M, et al. Multifunctional dendrimer-modified multiwalled carbon nanotubes: synthesis, characterization, and in vitro cancer cell targeting and imaging. Biomacromolecules. 2009;10(7): $1744-1750$

36. Yang J, Zhang Z, Men X, Xu X, Zhu X. Reversible superhydrophobicity to superhydrophilicity switching of a carbon nanotube film via alternation of UV irradiation and dark storage. Langmuir. 2010;26(12): 10198-10202.

37. Holt BD, Short PA, Rape AD, Wang YL, Islam MF, Dahl KN. Carbon nanotubes reorganize actin structures in cells and ex vivo. ACS Nano. 2010;4(8):4872-4878.

38. Aschberger K, Johnston HJ, Stone V, et al. Review of carbon nanotubes toxicity and exposure - appraisal of human health risk assessment based on open literature. Crit Rev Toxicol. 2010;40(9):759-790.

39. Shams H, Holt BD, Mahboobi SH, et al. Actin reorganization through dynamic interactions with single-wall carbon nanotubes. ACS Nano. 2014;8(1):188-197.

40. Sarkaria JN, Kitange GJ, James CD, et al. Mechanisms of chemoresistance to alkylating agents in malignant glioma. Clin Cancer Res. 2008; 14(10):2900-2908.

41. Gladson CL, Prayson RA, Liu WM. The pathobiology of glioma tumors. Annu Rev Pathol. 2010;5:33-50.

42. Ouyang M, White EE, Ren H, et al. Metronomic doses of temozolomide enhance the efficacy of carbon nanotube $\mathrm{CpG}$ immunotherapy in an invasive glioma model. PLoS One. 2016;11(2):e0148139.

43. Han YG, Xu J, Li ZG, Ren GG, Yang Z. In vitro toxicity of multiwalled carbon nanotubes in C6 rat glioma cells. Neurotoxicology. 2012; 33(5):1128-1134.

44. Nimmagadda A, Thurston K, Nollert MU, McFetridge PS. Chemical modification of SWNT alters in vitro cell-SWNT interactions. J Biomed Mater Res A. 2006;76(3):614-625.

45. Vakarelski IU, Brown SC, Higashitani K, Moudgil BM. Penetration of living cell membranes with fortified carbon nanotube tips. Langmuir. 2007;23(22):10893-10896.

46. Albini A, Mussi V, Parodi A, et al. Interactions of single-wall carbon nanotubes with endothelial cells. Nanomedicine. 2010;6(2):277-288.

47. Jin H, Heller DA, Sharma R, Strano MS. Size-dependent cellular uptake and expulsion of single-walled carbon nanotubes: single particle tracking and a generic uptake model for nanoparticles. ACS Nano. 2009;3(1):149-158.

48. Jin H, Heller DA, Strano MS. Single-particle tracking of endocytosis and exocytosis of single-walled carbon nanotubes in NIH-3T3 cells. Nano Lett. 2008;8(6):1577-1585.

49. Heller DA, Jin H, Martinez BM, et al. Multimodal optical sensing and analyte specificity using single-walled carbon nanotubes. Nat Nanotechnol. 2009;4(2):114-120.

50. Kam NW, Dai H. Carbon nanotubes as intracellular protein transporters: generality and biological functionality. J Am Chem Soc. 2005; 127(16):6021-6026.

51. Maruyama K, Haniu H, Saito N, et al. Endocytosis of multiwalled carbon nanotubes in bronchial epithelial and mesothelial cells. Biomed Res Int. 2015;2015:793186.

52. Zhang M, Ye G, Li J, Wang Y. Recent advance in molecular angiogenesis in glioblastoma: the challenge and hope for anti-angiogenic therapy. Brain Tumor Pathol. 2015;32(4):229-236. 
53. Lindberg HK, Falck GC, Suhonen S, et al. Genotoxicity of nanomaterials: DNA damage and micronuclei induced by carbon nanotubes and graphite nanofibres in human bronchial epithelial cells in vitro. Toxicol Lett. 2009;186(3):166-173.

54. Ye S, Jiang Y, Zhang H, et al. Multi-walled carbon nanotubes induce apoptosis in RAW 264.7 cell-derived osteoclasts through mitochondriamediated death pathway. J Nanosci Nanotechnol. 2012;12(3): 2101-2112.

55. Pongrakhananon V, Luanpitpong S, Stueckle TA, Wang L, Nimmannit U, Rojanasakul Y. Carbon nanotubes induce apoptosis resistance of human lung epithelial cells through FLICE-inhibitory protein. Toxicol Sci. 2015;143(2):499-511.

56. Zeni O, Sannino A, Romeo S, Micciulla F, Bellucci S, Scarfi MR. Growth inhibition, cell-cycle alteration and apoptosis in stimulated human peripheral blood lymphocytes by multiwalled carbon nanotube buckypaper. Nanomedicine (Lond). 2015;10(3):351-360.

57. Nam CW, Kang SJ, Kang YK, Kwak MK. Cell growth inhibition and apoptosis by SDS-solubilized single-walled carbon nanotubes in normal rat kidney epithelial cells. Arch Pharm Res. 2011;34(4):661-669.

58. Siegrist KJ, Reynolds SH, Kashon ML, et al. Genotoxicity of multiwalled carbon nanotubes at occupationally relevant doses. Part Fibre Toxicol. 2014;11:6.

59. Brown GC, Borutaite V. Inhibition of mitochondrial respiratory complex I by nitric oxide, peroxynitrite and S-nitrosothiols. Biochim Biophys Acta. 2004;1658(1-2):44-49.
60. Castranova V. Signaling pathways controlling the production of inflammatory mediators in response to crystalline silica exposure: role of reactive oxygen/nitrogen species. Free Radic Biol Med. 2004; 37(7):916-925.

61. Geiser M, Rothen-Rutishauser B, Kapp N, et al. Ultrafine particles cross cellular membranes by nonphagocytic mechanisms in lungs and in cultured cells. Environ Health Perspect. 2005;113(11):1555-1560.

62. Xu C, Liu Q, Liu H, Zhang C, Shao W, Gu A. Toxicological assessment of multi-walled carbon nanotubes in vitro: potential mitochondria effects on male reproductive cells. Oncotarget. 2016;7(26):39270-39278.

63. Domingues P, González-Tablas M, Otero Á, et al. Tumor infiltrating immune cells in gliomas and meningiomas. Brain Behav Immun. 2016;53:1-15.

64. Boyles MS, Young L, Brown DM, et al. Multi-walled carbon nanotube induced frustrated phagocytosis, cytotoxicity and pro-inflammatory conditions in macrophages are length dependent and greater than that of asbestos. Toxicol In Vitro. 2015;29(7):1513-1528.

65. Visalli G, Bertuccio MP, Iannazzo D, Piperno A, Pistone A, Di Pietro A. Toxicological assessment of multi-walled carbon nanotubes on A549 human lung epithelial cells. Toxicol In Vitro. 2015;29(2):352-362.

66. Aldieri E, Fenoglio I, Cesano F, et al. The role of iron impurities in the toxic effects exerted by short multiwalled carbon nanotubes (MWCNT) in murine alveolar macrophages. J Toxicol Environ Health A. 2013;76(18):1056-1071. 


\section{Supplementary materials}
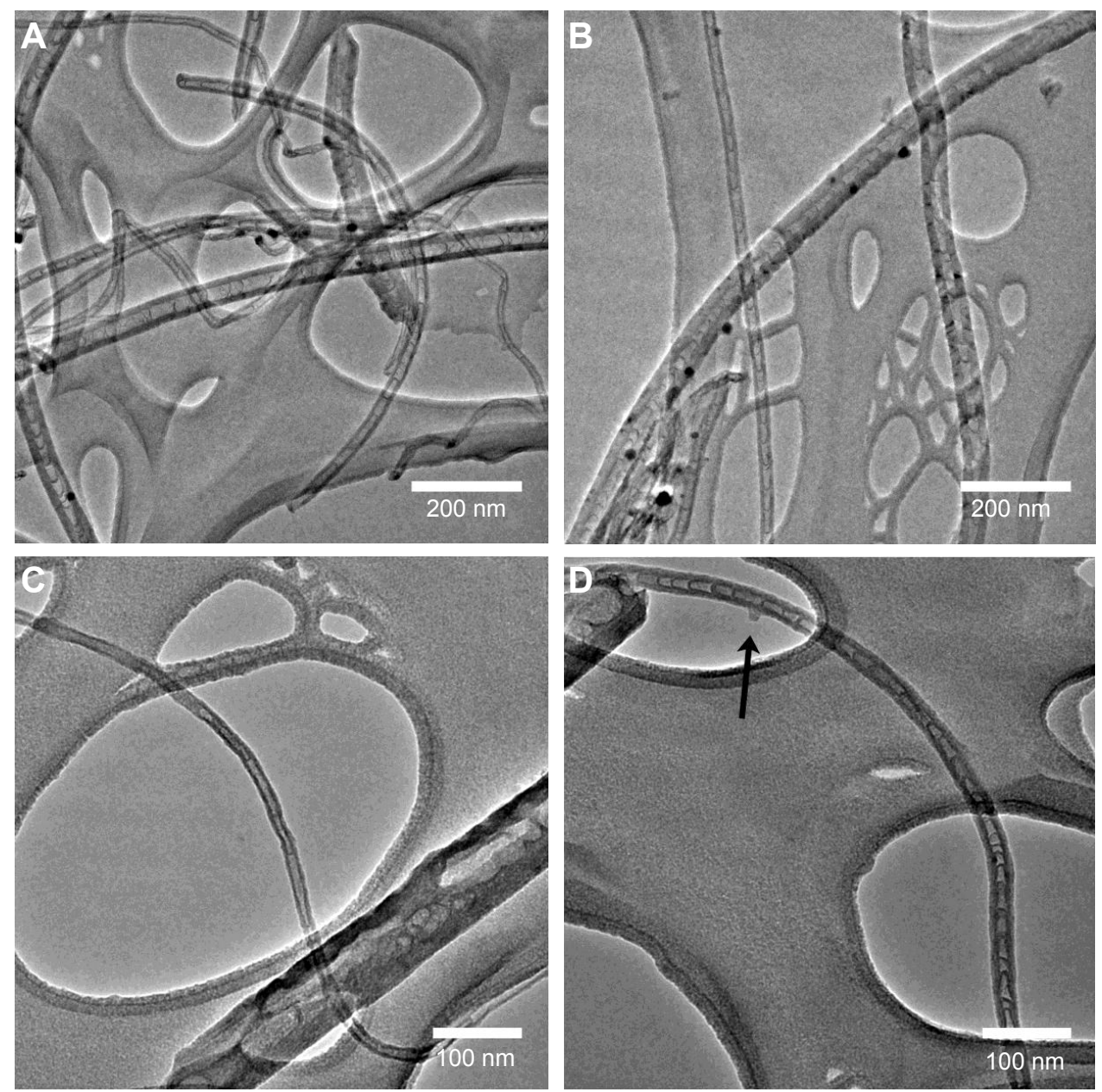

Figure SI TEM images of typical N-MWCNTs before (A and $\mathbf{B})$ and after $(\mathbf{C}$ and $\mathbf{D})$ acid treatment.

Notes: Most particles attached to the nanotubes surface were eliminated with the acid treatment. Note in (D) a small protuberance that possibly contained a metallic nanoparticle (arrow).

Abbreviations: TEM, transmission electron microscopy; N-MWCNTs, nitrogen-doped multiwalled carbon nanotubes.
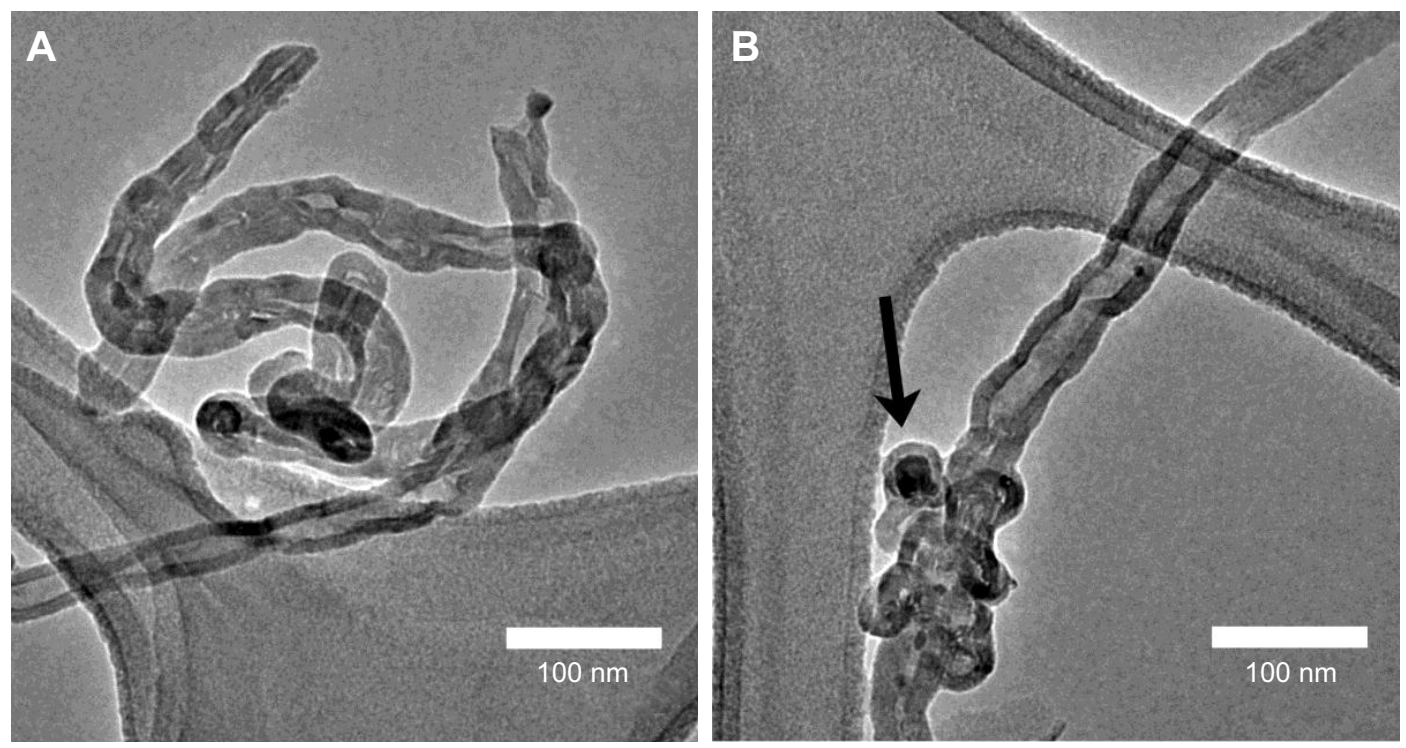

Figure S2 (Continued) 

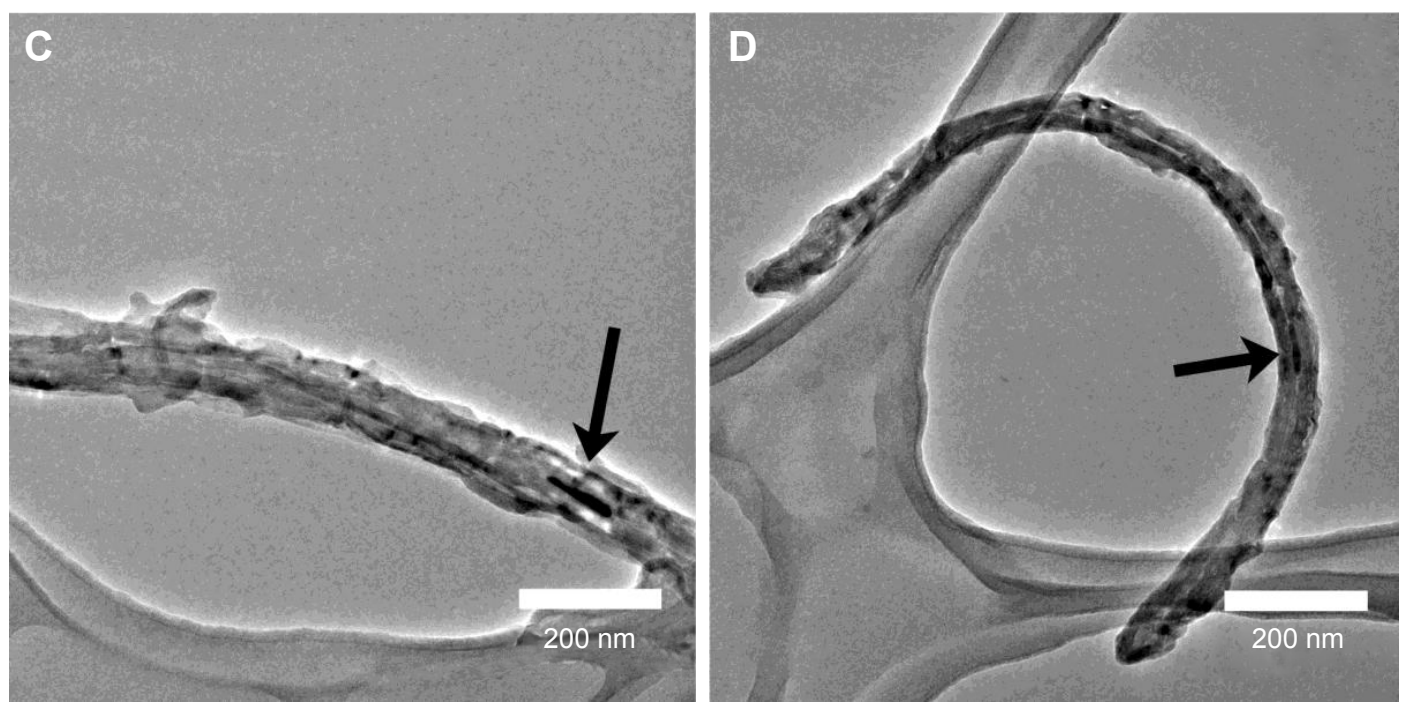

Figure S2 TEM images of typical MWCNTs (undoped) before (A and B) and after (C and D) acid treatment.

Notes: Most of the metallic nanoparticles are inside the pristine carbon nanotubes ( $\mathbf{A}$ and $\mathbf{B})$. Besides the elimination of such nanoparticles, acid treatments provoked severe damages on the MWCNTs surface (C and $\mathbf{D})$. The arrows show the damage provoked by the acid treatment in the MWCNTs surface.

Abbreviations: TEM, transmission electron microscopy; MWCNTs, multiwalled carbon nanotubes.
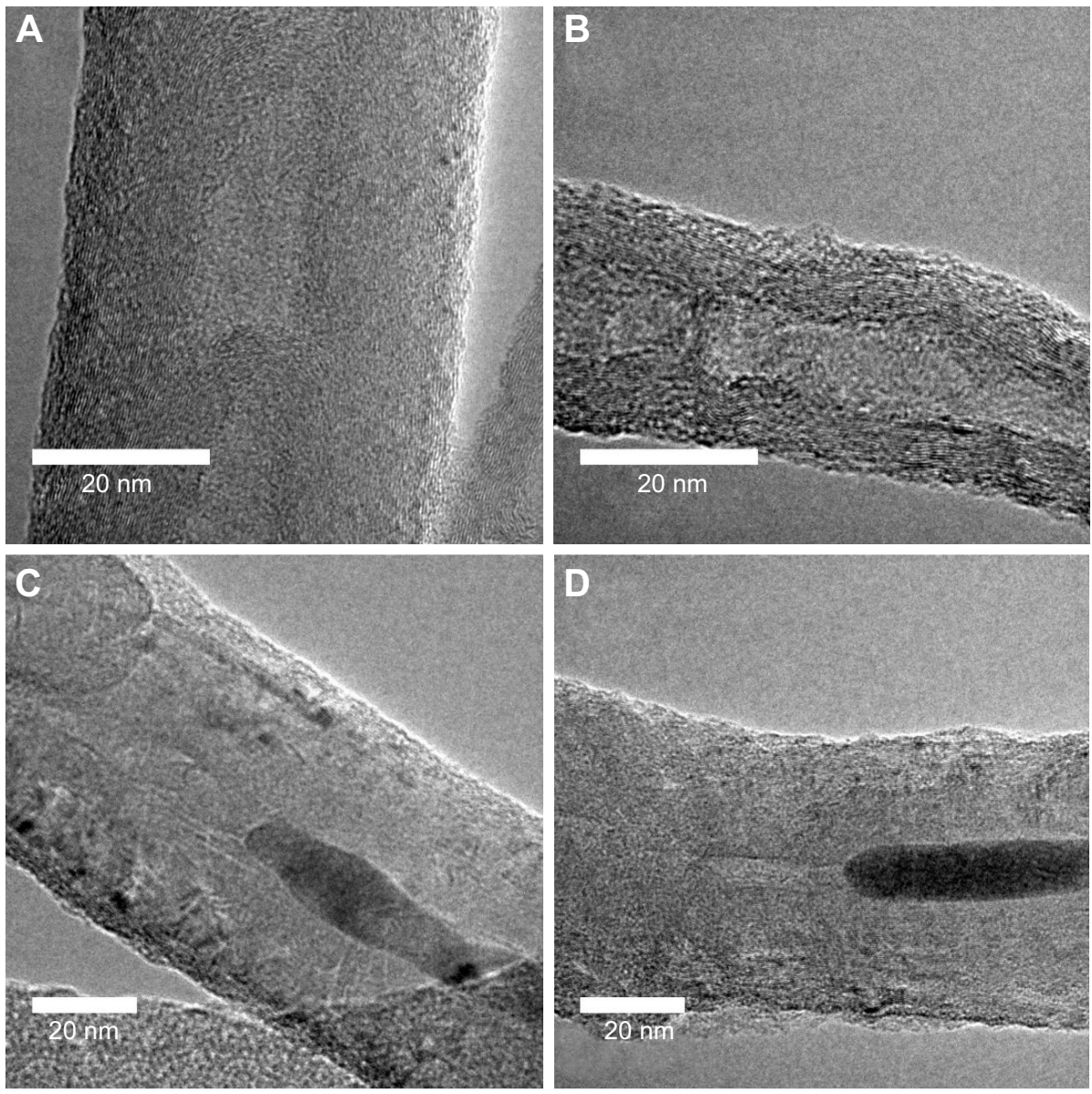

Figure S3 HRTEM images showing the morphological aspects of different CNTs used in this study.

Notes: A pristine N-MWCNT of $\sim 46-\mathrm{nm}$ diameter showing typical compartments of bamboo-like shape of nanotubes (A). A functionalized N-MWCNT showing surface damage probably provoked by the acid treatment; the loss of diameter uniformity is also perceptible (B). A pristine MWCNT having an internal iron carbide nanoparticle; the diameter of this carbon nanotube is $\sim 60 \mathrm{~nm}$ (C). An MWCNT with acid treatment; although in this case the internal nanoparticle did not suffer damage because the lateral cavities were blocked, the surface was damaged by the acid treatment (D).

Abbreviations: HRTEM, high-resolution transmission electron microscopy; CNTs, carbon nanotubes; N-MWCNT, nitrogen-doped MWCNT; MWCNT, multiwalled carbon nanotube. 

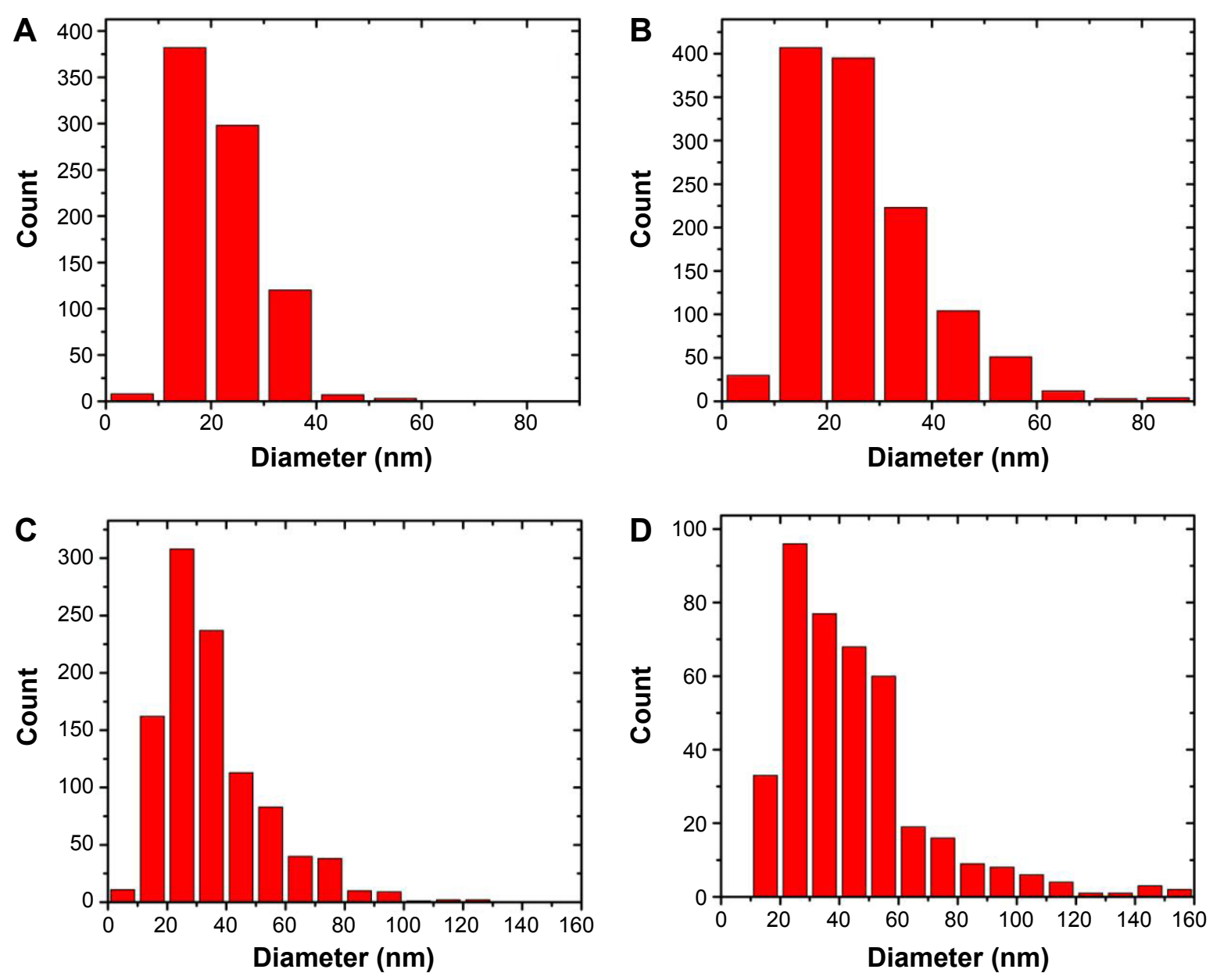

Figure S4 Column plots showing diameter distribution corresponding to each kind of CNTs studied in this work.

Notes: Pristine N-MWCNTs exhibit an average diameter of $22.2 \mathrm{~nm}$. In this case, the minimum diameter found was $\sim 7 \mathrm{~nm}$, and the maximum was $\sim 60 \mathrm{~nm}$ (A). Acidtreated N-MWCNTs where the minimum diameter found was $5.8 \mathrm{~nm}$ and the maximum was $87 \mathrm{~nm}$ with an average of $26.4 \mathrm{~nm}$ (B). Pristine MWCNTs with diameters ranging between 7 and $129 \mathrm{~nm}$, and an average diameter of $35.3 \mathrm{~nm}(\mathbf{C})$. Acid-treated MWCNTs present an average diameter of $44 \mathrm{~nm}$, a minimum diameter of $13 \mathrm{~nm}$ and a maximum diameter of $154 \mathrm{~nm}$ (D). These results may seem contradictory because the amount of acid-treated CNTs with a broad diameter increased. However, it is possible that thick nanotubes could break due to the influence of the acid, increasing the amount of large-diameter CNTs.

Abbreviations: CNTs, carbon nanotubes; N-MWCNTs, nitrogen-doped MWCNTs; MWCNT, multiwalled carbon nanotube.

\section{Publish your work in this journal}

The International Journal of Nanomedicine is an international, peerreviewed journal focusing on the application of nanotechnology in diagnostics, therapeutics, and drug delivery systems throughout the biomedical field. This journal is indexed on PubMed Central, MedLine, CAS, SciSearch $®$, Current Contents ${ }^{\circledR} /$ Clinical Medicine,
Journal Citation Reports/Science Edition, EMBase, Scopus and the Elsevier Bibliographic databases. The manuscript management system is completely online and includes a very quick and fair peer-review system, which is all easy to use. Visit http://www.dovepress.com/ testimonials.php to read real quotes from published authors. 